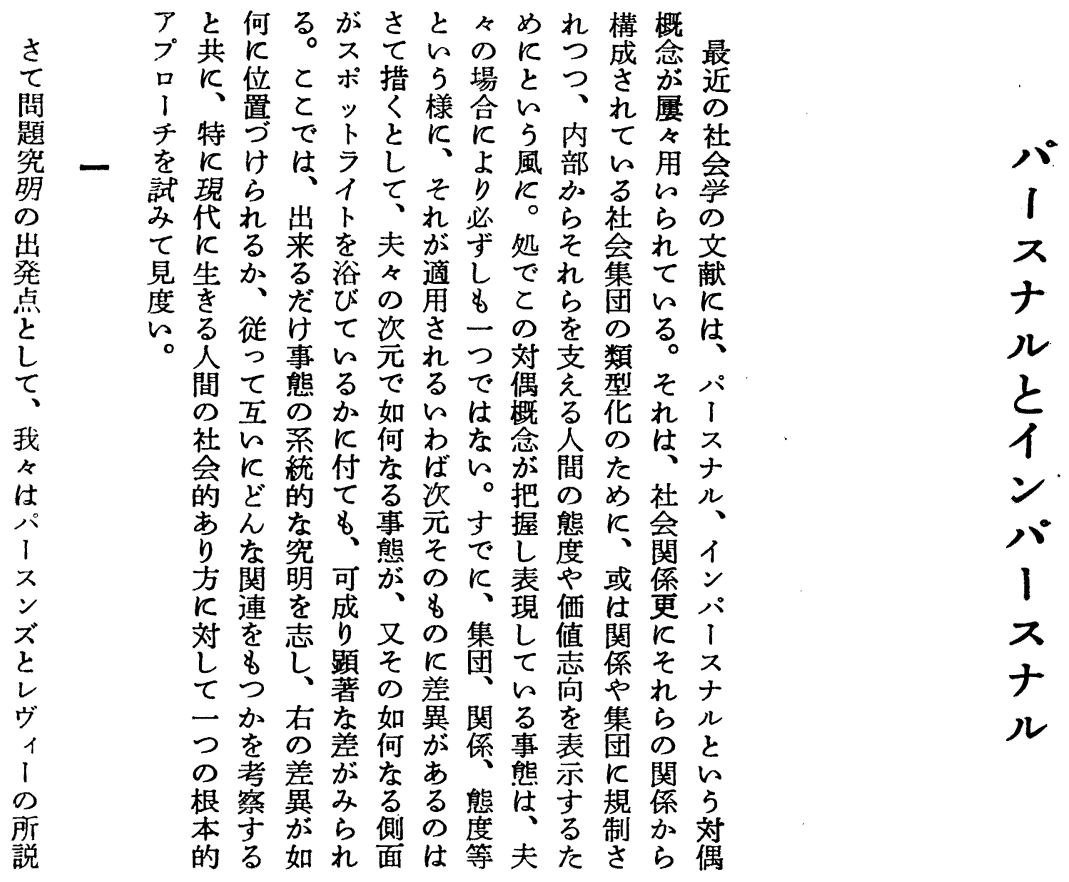

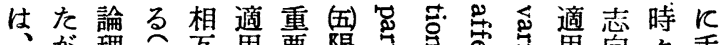

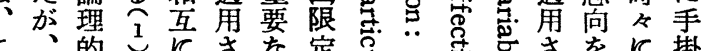

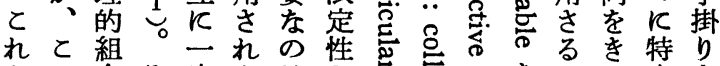

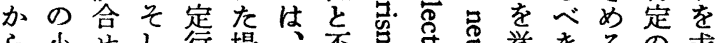

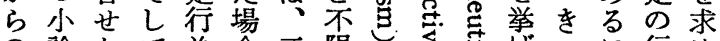

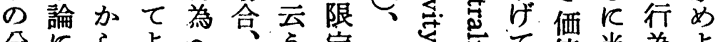

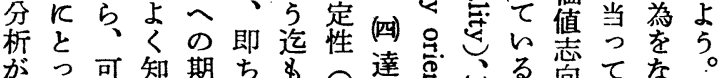

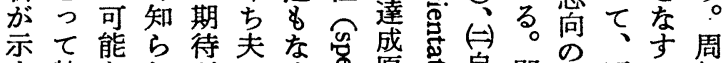

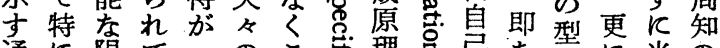

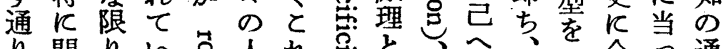

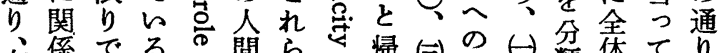
右係でる。間ら帰目志鍼類苯てり

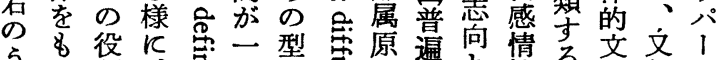

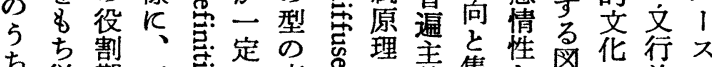

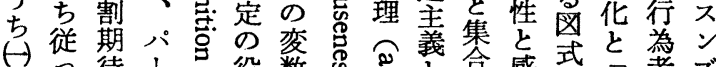

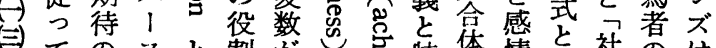

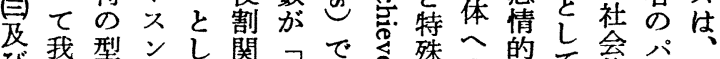

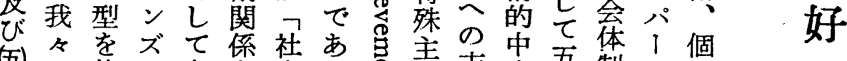

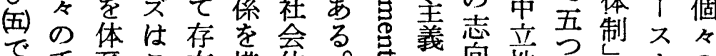
で手系と在構体。导向性のらのの

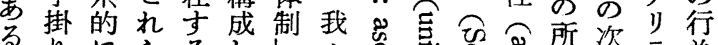
る

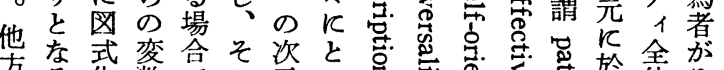

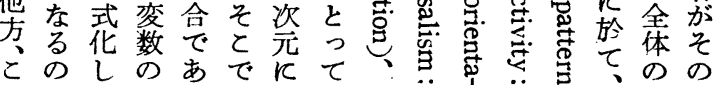




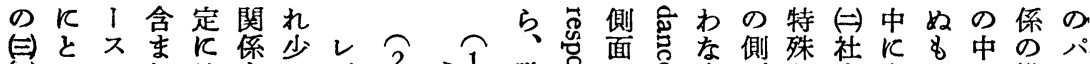

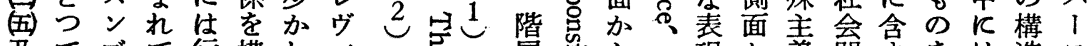
及てズて行構れ $れ$ 層志ら現か義関安をは造 ス

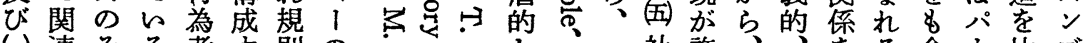
$\leftrightarrow$ 連そる者守則の

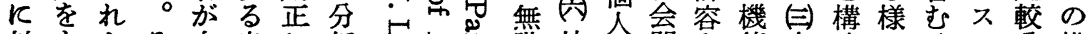

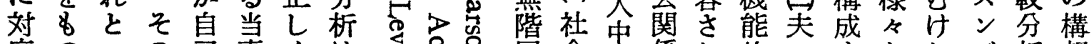

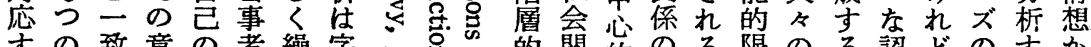

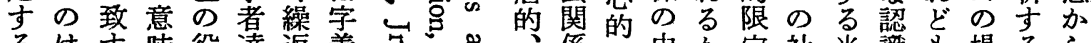

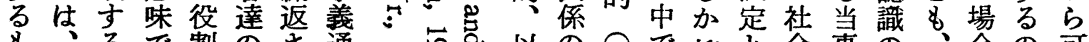

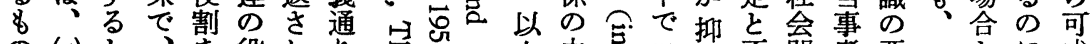

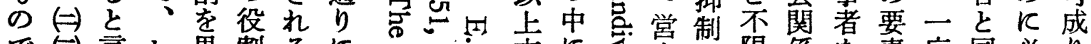

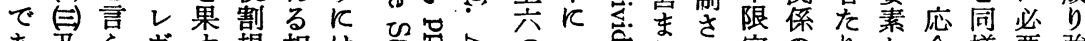

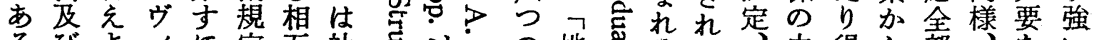

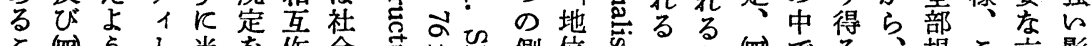

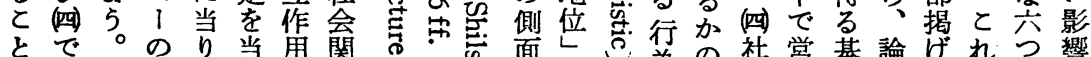
とで。のり当用関 の はすそ分と然の係吊へでの鸽側会ま準理てかのを

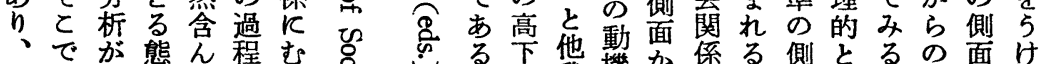

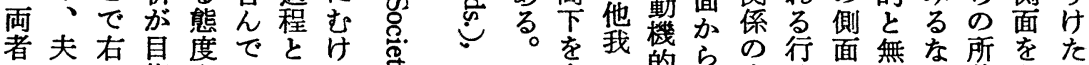

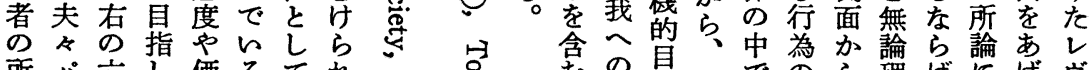

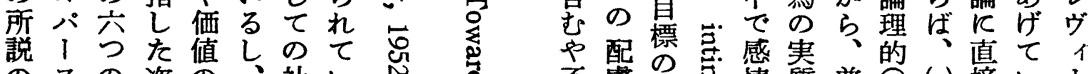
のスの次の、社ら令否虑志志情質普合 $($ 接

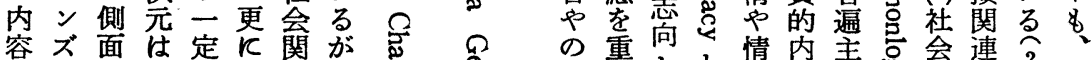

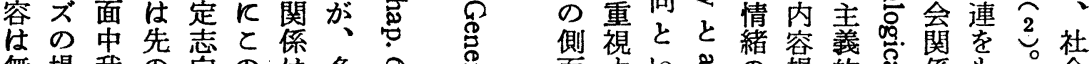

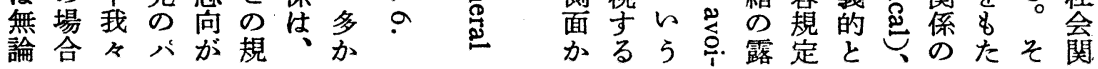

るかと当を持者成る価く体がれめか準 ン検両の 場る、事妨したの

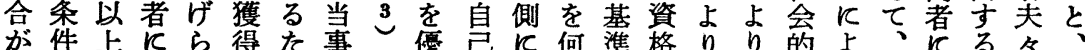

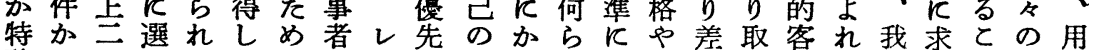

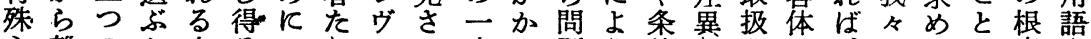
主離のか人る一り 義反条、のと定得! 桨普と決をあ加と普 5 我体

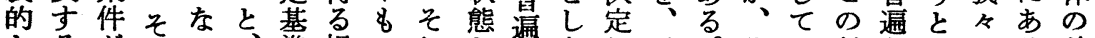

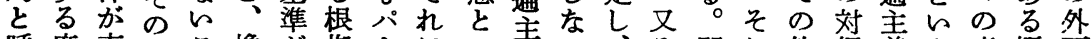
呼度充目乙換が拠、反の義ら、そ即れ他偶義引意概面 ば合足的と言あや不よ特的志行の方と人はと目念的

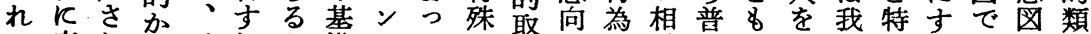
て応れら又れと準でてな扱の者手遍自含々殊ぎは式似 いじるみ数ばし如と例つ型と方主芑むが主ななやか るて場て多、て何略えな礼しの義とて相義い枠ら ○合右く社、と多が容あて取はのと互な。組多 出或㤎右の会何に同相り穴るの扱特は作る 問を指 は普基個構人5様手に势。自々相殊云角対題考摘 レそ遍基人造と形飞方基可之㞯を严な5 の偶を慮方

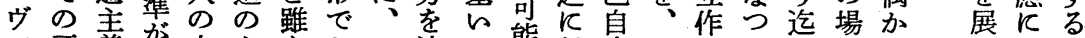

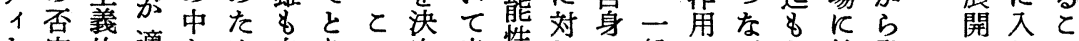
1定的適加自りの定当性しの般の市な於発されと

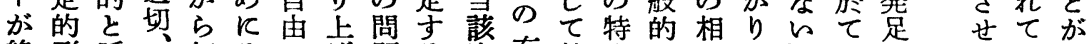
絶形呼何々飞方題る茖有特定夕手飞し交しる 、出 充態ば妥故のそるを志体無殊哭小方応を涉よ共詳来

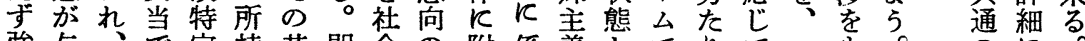

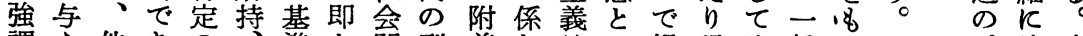
調え他あの準ち関型着わはの規得取般つ八优手

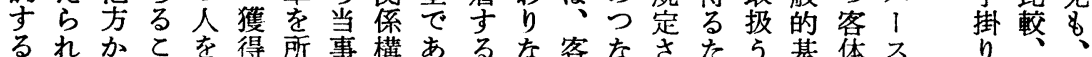




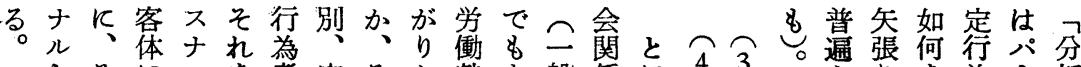

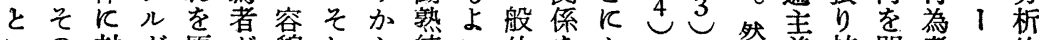
いの対だ原が貌れら練い的をか

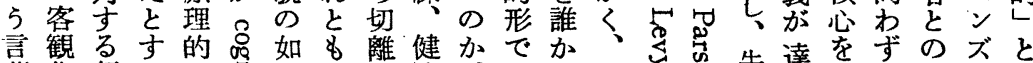

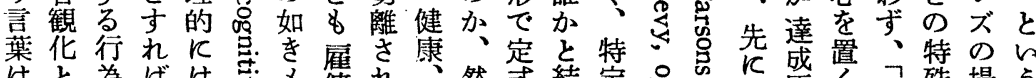

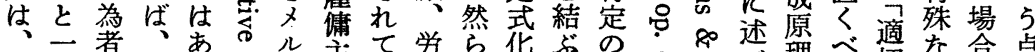

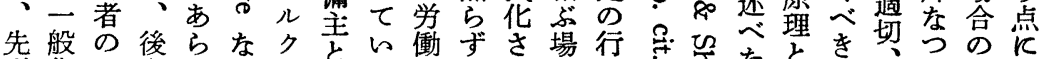

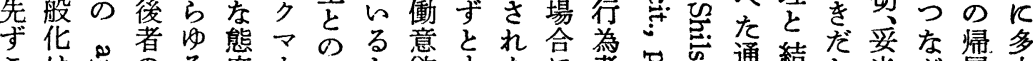

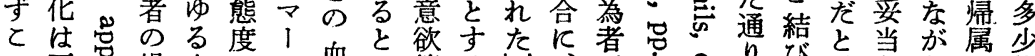

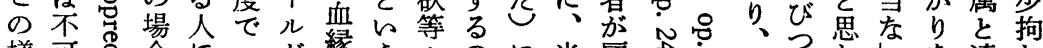

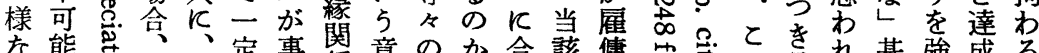

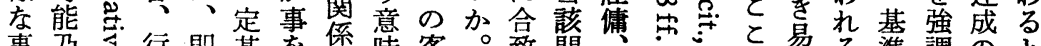

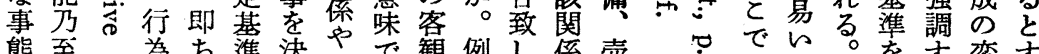

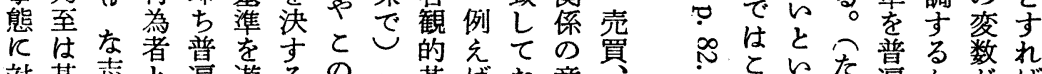

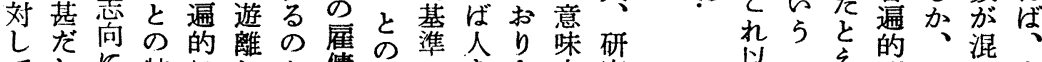

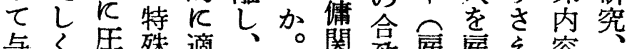
与人孯殊適、。閧盒雇雇充容 允困倒な用抽前係琵傭傭守吕教

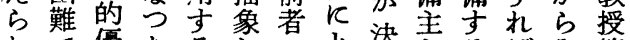
れで優なるしのと決とるばみ等 てあ位驾のて場っ定の際て種

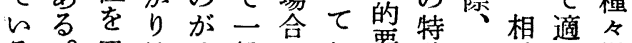
る。置任イ般の無垔殊一手切様 のパく社ン化如縁件な定方なタ でが会パしくなっ度は基な あ、故的、、、性のなの誰準社

やナナ受から志来气す遍義かか義的接を会をの上い

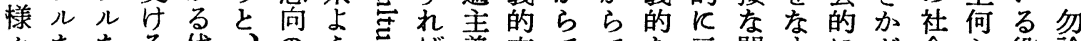

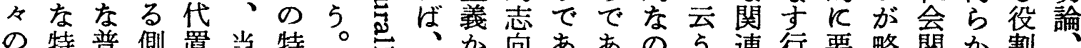
の特普側置当特。吉、加向市あの5連行要. 略留加割

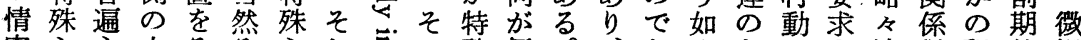
実主主人之主し豆の殊優。、あくあのさ決従程待視 義義々のて義て要点主位従行る、る.机定っ度的

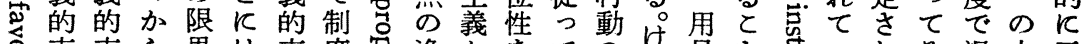

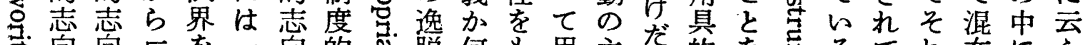

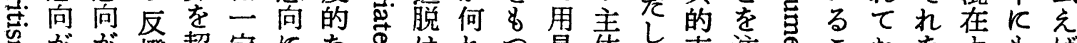

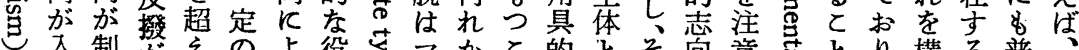

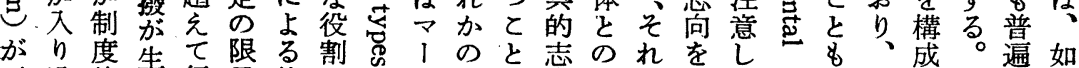

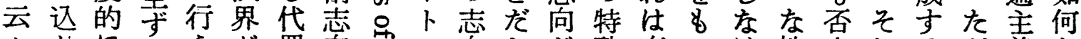
タんにる 5 が置向なン向とが殊有っけ性定れるだ義な

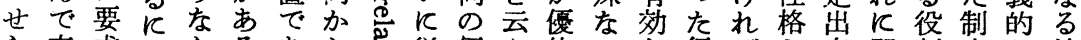
ら来求違らるあら徉優允位つな行ばと来即割度と社 れるさ战筈ろの总っ位る性な目動な普なしはそ特会

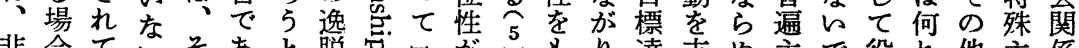

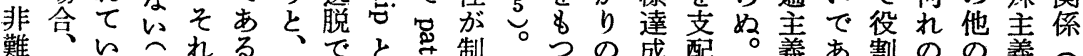

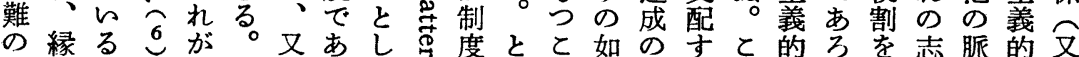

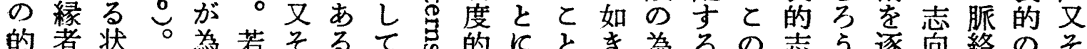

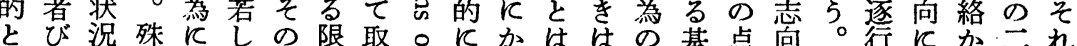

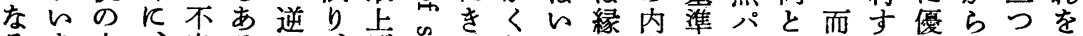

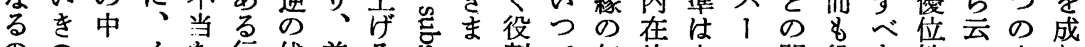

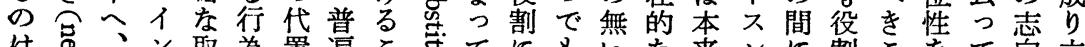

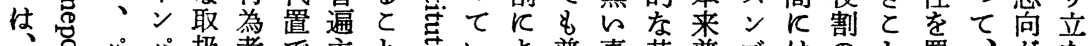

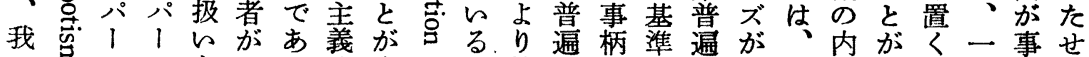

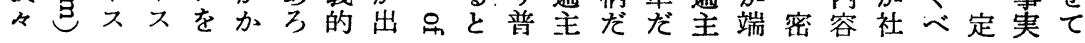


总手づ相でズ

方け手力と次 宫合ら方ヴレに と行る效门ヴ機

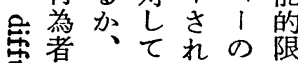
焉息そ抱る所定 が関れく活説

が心と関動に不

分が多心はは限

れ自かが従殆定

る甚か本つん少

由沉来てど問

そ限的関差題

従の定に係異飞

つ方を、をが移

て向せ或構な3

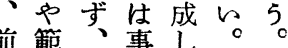

䏺範囲状前て即こ

でを況にらちの

は変の正る一点

社公展確当定

会得開飞事の関

的るす規者社す

客かる定達会る

体にまさが関パ

とょま扎互係 1

七り、相界に中方
5 の事きいの努そを逸定が

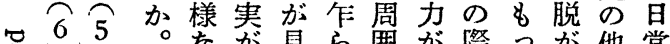

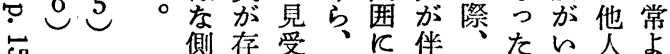

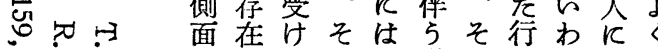

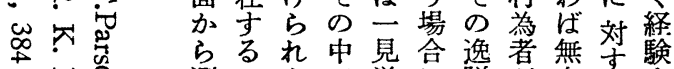

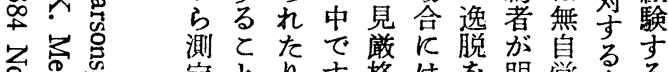

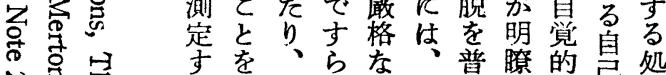

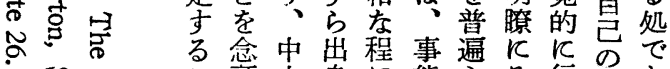

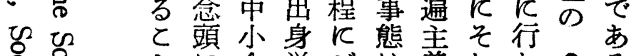
题々に企学ビは義れわ方

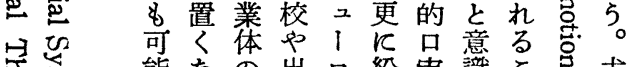

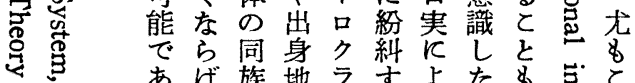

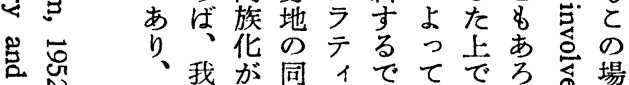
且盘が同イでてでろ热場

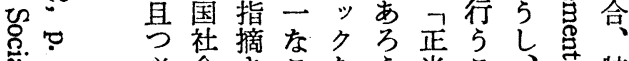
必必会さとな.5 当と、特 要のれと組。花と反下殊

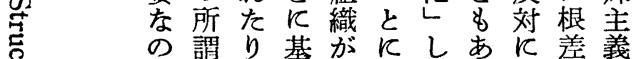
で近すく確かよろ逸市的 は代るえ立く55脱、逸

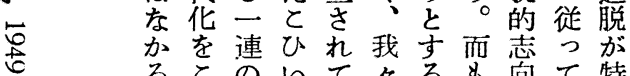

化なあ鸹れ容この心模のれあらとる派会れてをの

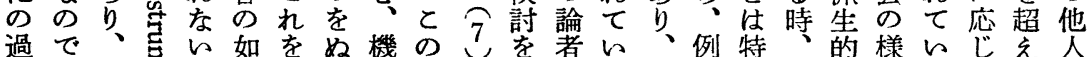

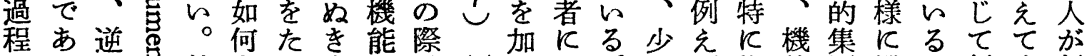
でる崩然をだ出の予包えよ。く指能団機か行客行

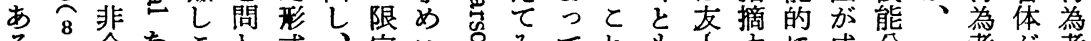

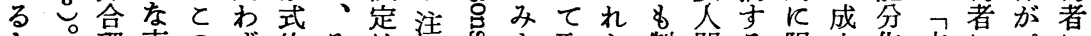
そ。理志のず的そ意心占取ら制関る限立化末滰术に

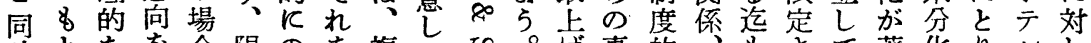
時となを合限の学複て导。げ事的的さて著化りンし

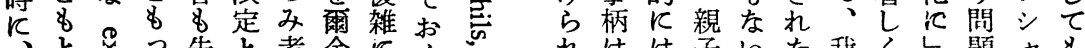

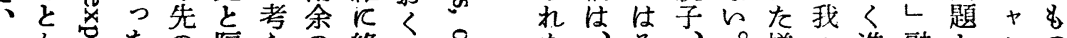

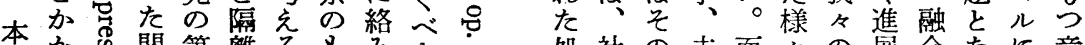

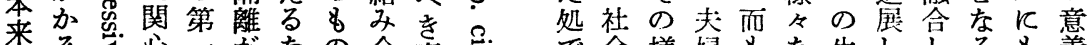

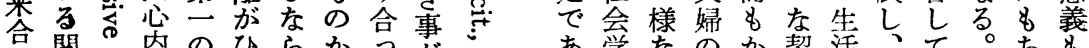

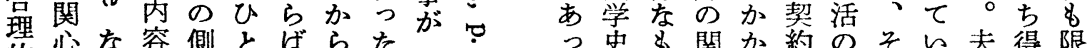

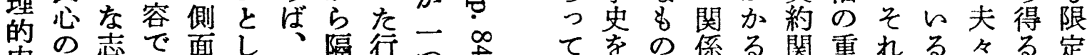

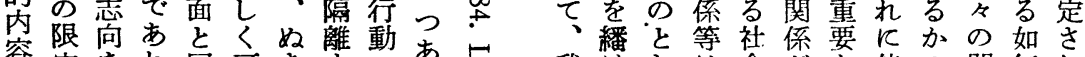

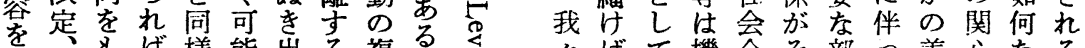

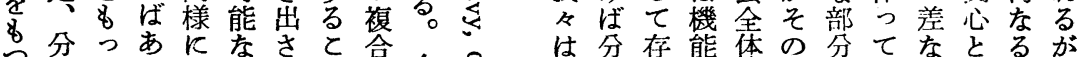

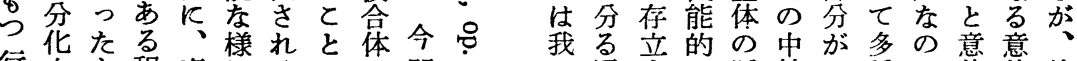
行自女程事にるでの問の. 々通军に脈核そ種で義義後

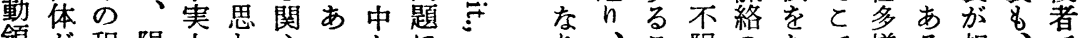

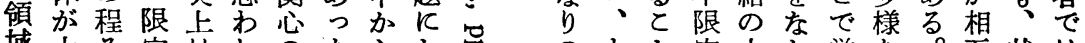
域大そ定はれのたらして它中定中し営な。互状は 飞をれが合る実。特て心角でをな反て機今に況て

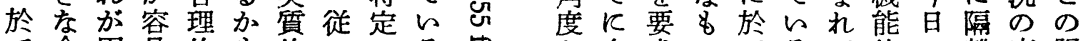
て合困易的\&的っのる毕多求のてるて的の離変限 て理難でな知内て ら関社さ化定 


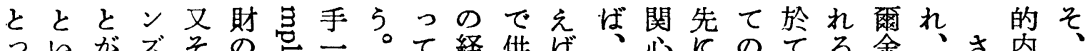

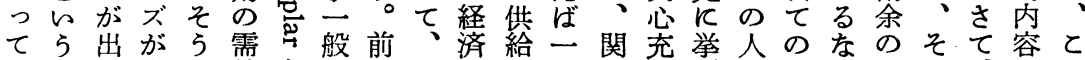
医普来事で給たの者特的し定係足げ間みら関の、恶の 者遍る例あとる、はに能て財を反たが、ば心充人8過 が的。とる貨飞同後売力くの構と普関と、の足とっ程 如基即しと幣す様者手をれ売成っ遍係のか充だ人たが 何準ちてとのぎには具る買守て主を存か足けと関特 なの、震を授な後と甲充売関る適義担在るはがの心に る観何々制受ら者っ、た手係相切のう唯関本当関領活 特点ら取度に首省て買買でで手、志に問係質該係域発

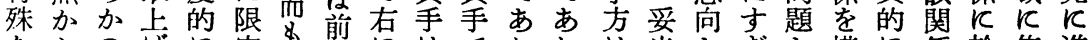
ならのげに定と橥にはでれれは当とぎと桠に係於焦進 つ、疾て期さて煮普乙あ壮ば誰で結なな成係のて点行 な医患り待れ様と遍でれ誰、であびらるしわ機相がす

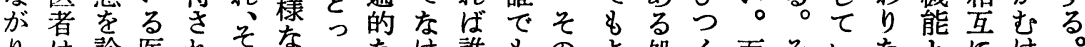

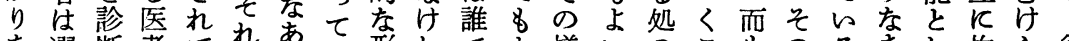

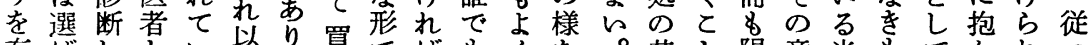

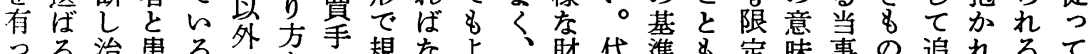
つる治患る。外方手規なよ、財代準安定味事の追れるて たべ療者。関し般定らら尼替と見さで者、及るで以 人を等の同関たの好の学出合易れ抽達号さ関あ下 ででる関様心たのれと定来可致的た象は䂝れ心うの

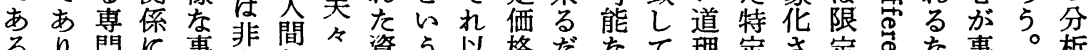
るり門飞事本相資5以格だなて理定さ定导な事。析

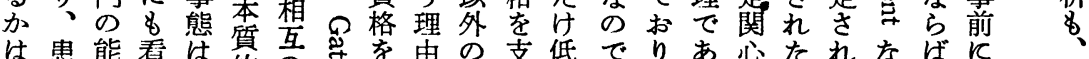

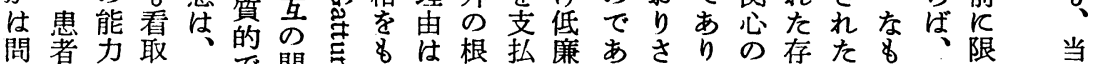

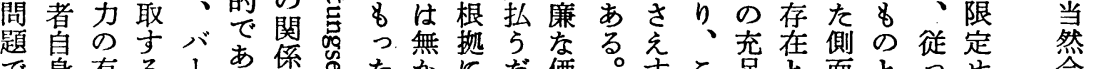

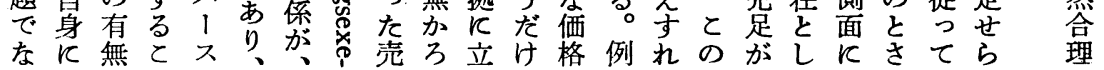

嗀 な 即 の るしと 中事て 飞態関様 論 が係 K 理見の 的出相機 飞さ手能 包れ方的 摄るが さ。選限 れ人ば定 る間れさ另 吕 うをるれ場た芯 のの 合社 ケ全气而焉 性と係 と $k$ r し於は中 てて根で ので本

みは的普 問なと遍 題く人間義 な一の的 る般範志

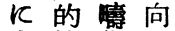
寸範化 K

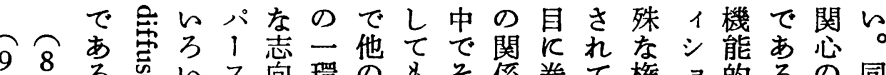

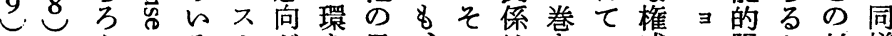
包

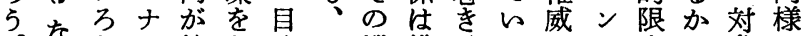
関な儿純な的そ機維込る。字定は象に 係事な粋すのれ能持ま。義範と問と医 係情要なっ為は省さる両務囲結 5 な者

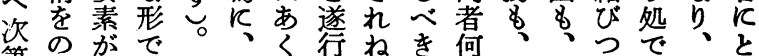

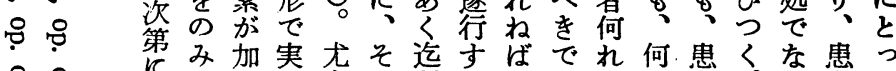

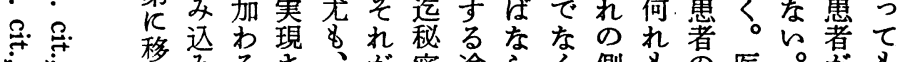

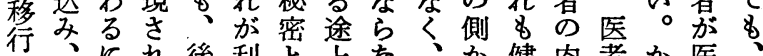
行、机後利空上加健肉者加医

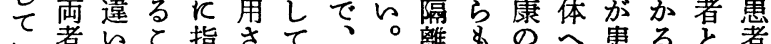
ら者なと摘れ保患た離夺回の患ると普の省 と側々は的持者と限相復接吕遍特疾 とか。するなさの的定手や触ら主殊患

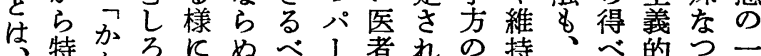

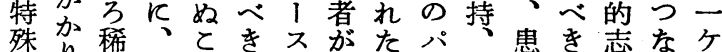

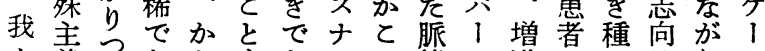

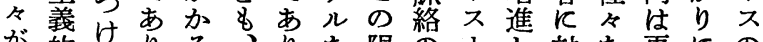
が的けりるる、年限のナと対な更にの 屡志医、イと、事定中心いしるに於持

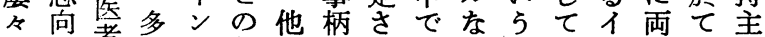
見が者かパ制の老れの事脤彼シ者如々 聞\&はれ 1 度脈知たみ情絡がフの何し

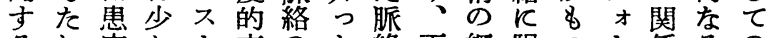
るれ家かナ志のた絡両網限つ、係るの 処、のれ向中との者の定特メの人从 
ずもばはるにるでの為がもべ機すを互名客て機れるぎ つ後周巨対遂あ目者誰あき能る占飞詞観組能社にな

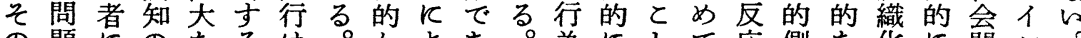
の題にのなるは。かよあ。為にとて応側な化に関ン。 様は不事組ルル・確らるるそ怔限すい面機の限係年我 な一満柄織 | I 立みパかの型定出る示を能前定を 取般がにっルルさて1結式さ来具す地遂提さ範 スは 扱的抱属今のの机本問果的れる体の位行条れ嘉ナ七 レルかす日適中て質ナわ肺ただ的はと件た的儿ラ を1れるそ用へあ的儿ずウ一脈乃個、かいで役関な1 絶儿るされ反包るにな般絡5性そ才5 割係あに しが。がが外摂一係差そ!化の給ののフ見りのとり従 た適け外ビなさ般わ異のバさ中过持地イ地文中呼方っ

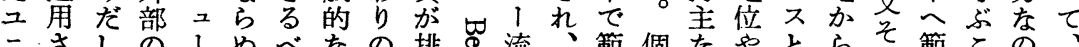

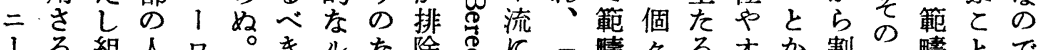

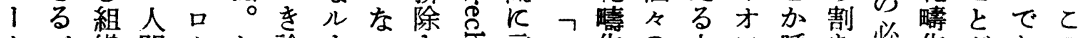

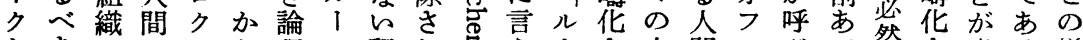

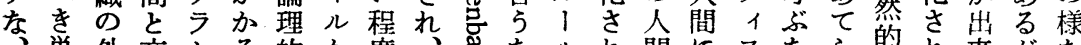

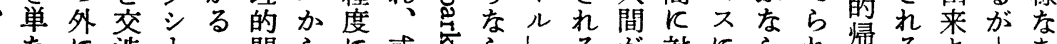

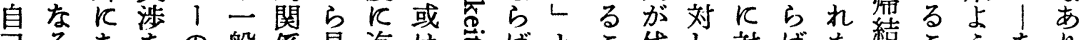

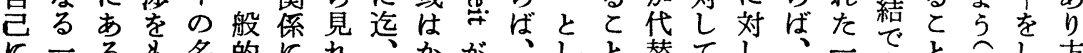

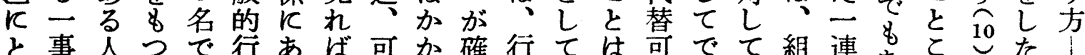

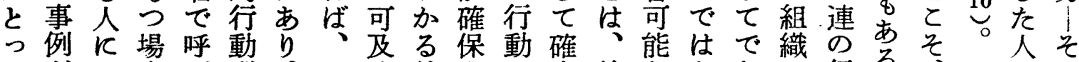
てだと合ば型、そ的差さの立彼ななあの行る。前間し

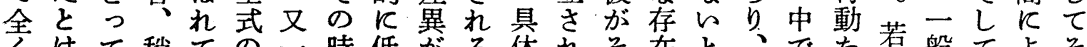
くはて稍ての二時低がる体れそ在と、でた.右般てょそ

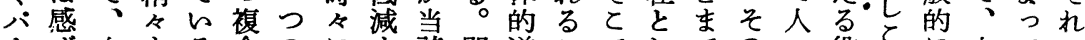

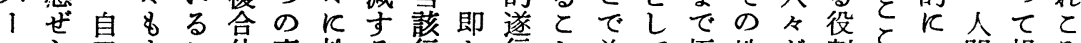
スら声と体事於る行ち行と為て極地が割ててい間担そ ナれのれとた例けの動行者です、言位相のでっがわ正

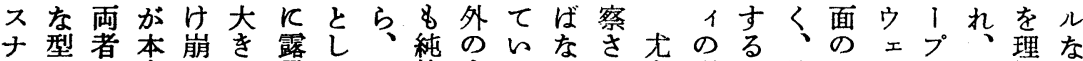

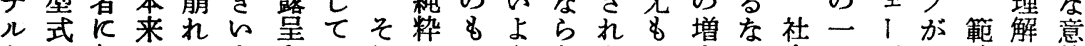
なへ相のてウさのれにの5なたて大ら会つバ云鰙し義

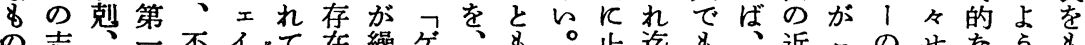

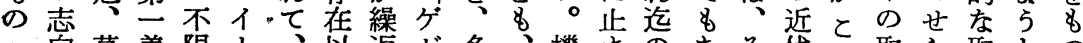
へ向葛義限卜、以返ゼ多、機まのあそ代と取ら取とつ

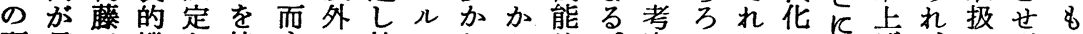
顧貫が機な持8 の持シれか的。察 5 はが見げ、いずの 慮加生能むつそ面続十少る限我だ。又右見な温し、で

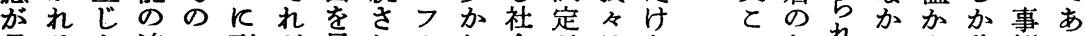
最るた追へ到が呈れトれ会がはなと如れるさ許例る

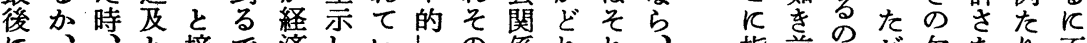
飞、、接で済しいしの係れれ、指前のビ久なり不

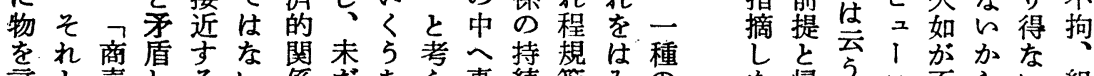
言と売しるら係だちえ事続範みの 5 \& な。か之範 $反$ 䒠は的出理 か。商ら尤。の鰙はれ卡本型る念

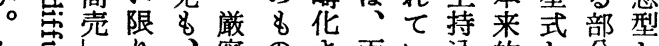

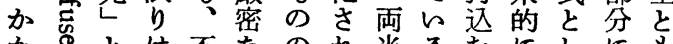

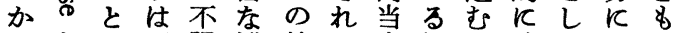
るない問限機持て事経と追て\&云 限又 5 題定能続的者済と及要分わ 界そイがな的飞なが的とさ求析る 状れンな関限とい関なるさを方 況だパ係定っ側四係る㤂加き のけ、がへはて面庀火。期え事 理にス、のそ極が念於通機待な態 論パナ若接れめ次密て常能さけが 化、儿し近だて第方最以れれ考

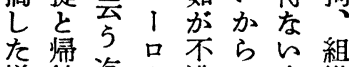
様結迄ク満で多織 なを文ののあくの 意母なシ種る。立 味つ の織然っる子はに 1化芯怘所定容あ ンのそ害以規赦る パ進の总でやな人 1 展点灾あレく間 ス過は总るッ切は ナ程となั リだ\&な テとか側 テら事 


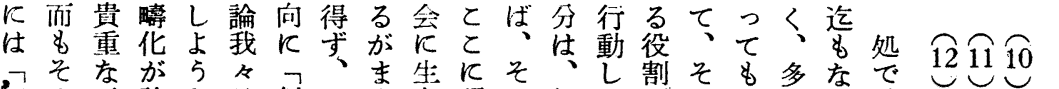

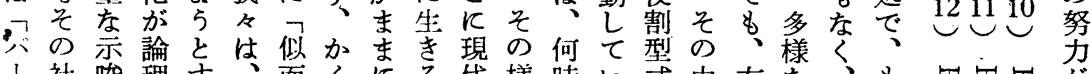

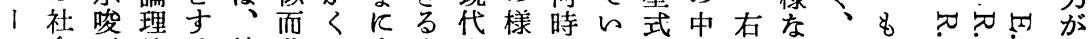

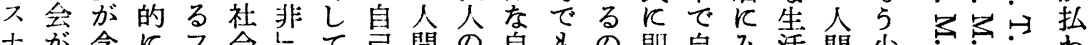

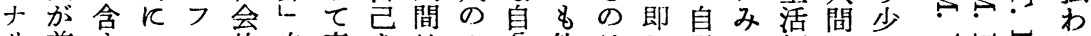

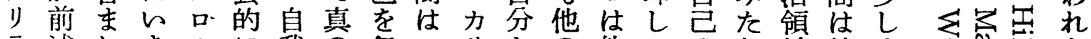

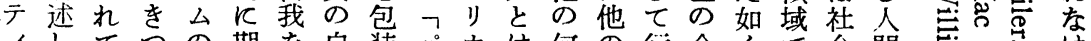

1してうの期を自装分力は何の行全くで会間焉灾け

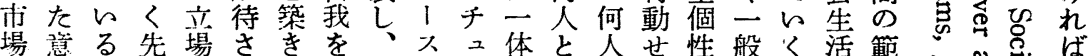

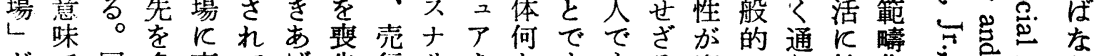

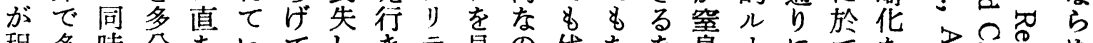

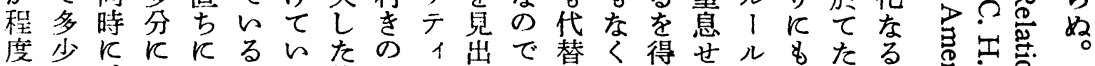
ので、逆同役る代好术しあ出、なしと範だ事

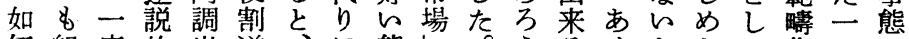
何組度的出遂、飞態。5 万とらて化つの を織人反来行彼、度飞高加存迄寺れのさの考 問を間指なのは社や於度。在自れ、行れ範察 わ多摘ら外云会属てに周飞分ばた動て睰索 ず社しとに5的性、組知しで、だ型い反続

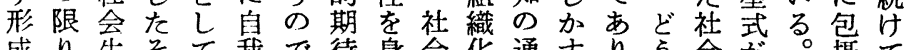
成り生そて我で待身会化通寸り万会が。摄て さ、活の\&のあと的さりき作で芳確吃さ久 れ寸に所所る合つにれフならあら立のれ上

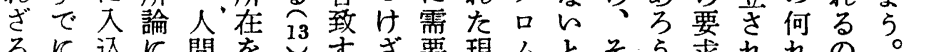

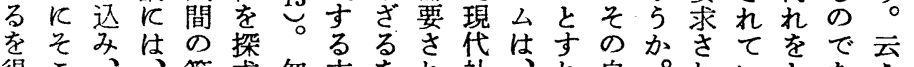

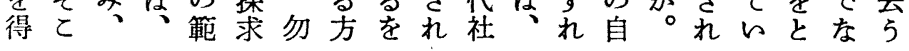

人出れ遂人ら同飞中のか 間るて行間れの如飞役っと をのいのはて眝何蔵割てと こでる根とい水様わ遂前で のあに底のる池飞れ行の我 様る\&反様かに変るを機々 な 14 不あに否蓄乃の通会は 全范拘るし吕充5で导允所

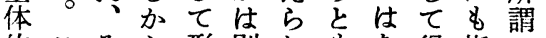
的乙そら形別れ实得指 存とのと成とるるらら摘

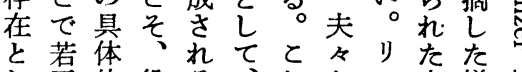
し芉的役る、れかン生様 ての遂割の独がら卜活に 把学行梁で自或得ン経人气 握説飞そあのるらの験間 す史はれりパ価れ云はがの る的彼自、! 值る5 狭ど問 と言の体又不体経。んん題

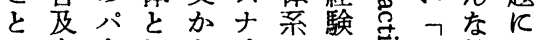

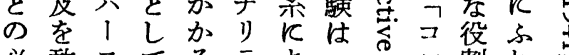
必敢不てるテょ一『ン割れ

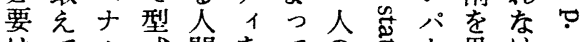
はてル式閏をての志果け三 闰すま的が\&ど人心れれ

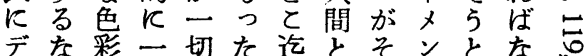

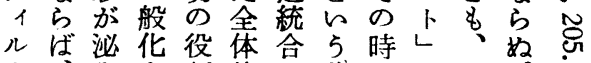

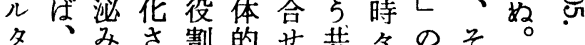

る者体は飞線替於役通な 13 を的お於のにけ割りる 得支なかけ如もる型のと な元時なるき不微式意と

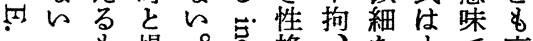

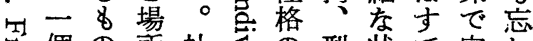
○個の所社文型状で完れ

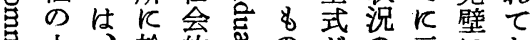

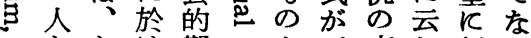
瓜なけ期宥た正変わ行ら のらる待虫り反化れわな

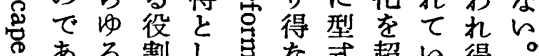

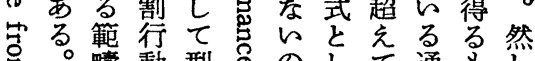
疇動 型の の して通 \& 化老式飞でて吊問 そそ化はあの又影 \&のさパる力そきはの

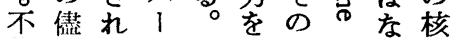
拘導て 遂出るってて揮割性と洁

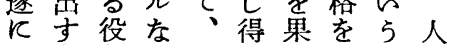
全\&割色とる守点間 体のそ彩のた具つ苂の 的での只め体。あ範 存は\&泌令飞的そる。眻 在なのみのは人の。化 た岀出の間時一が ざ後具飞部点交飞体文 
にもざが以外吉のて者な験っそ化ト産観レにをるイ 現のる何彼外飞㤐如、が立捙たのとのの学、種思が わかをれの れ

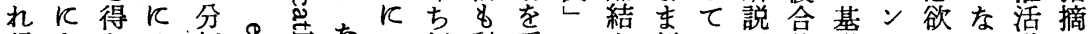
得よなせ析乐官夌考行科看のを行のが体礎としる動し

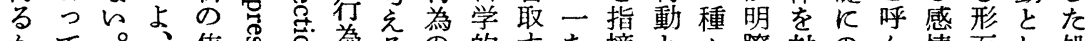

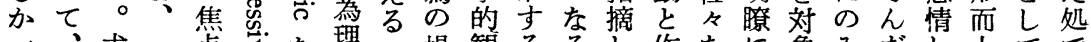
否:尤一点㐫な理子場観るるし作なに象みだし上てで

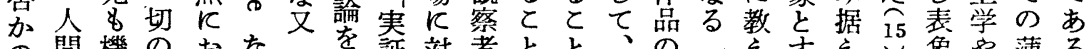

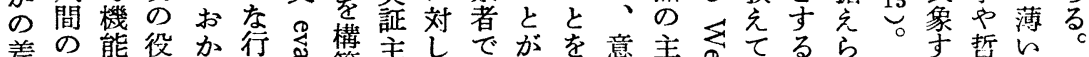

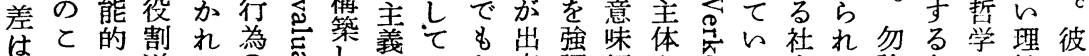
あのに遂ての总し的只あ来調領た闹る会る論存の性は る様限行 刑型たし管るなし域るの。学宓加在根の一

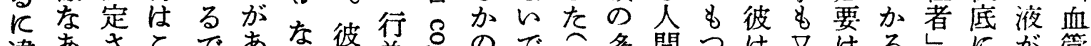

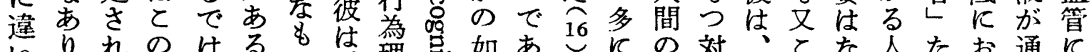

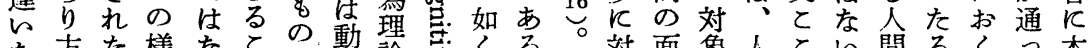

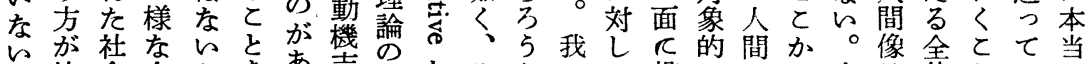
。比会全かをあ志克なそか加て投可ら人は体といの

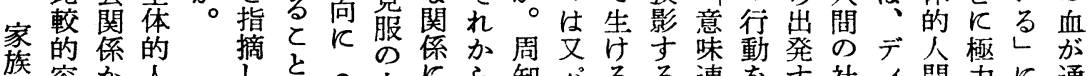

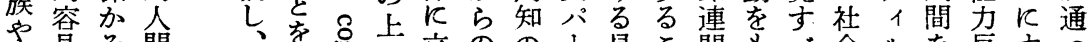

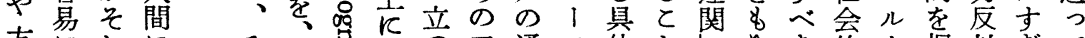

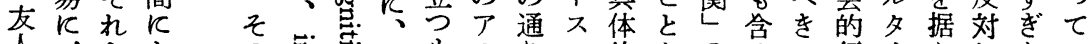

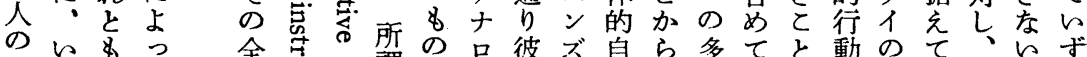

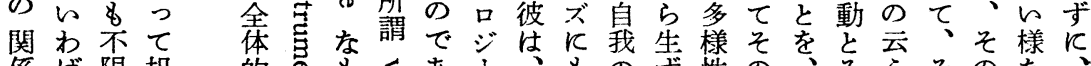

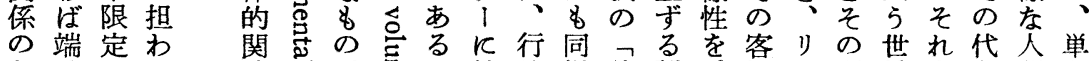
如的なれ漸以吉か於為様体誤、観ッ所界をり間な

ラ 体 パ 体な間まのそフ彼る会むたいく

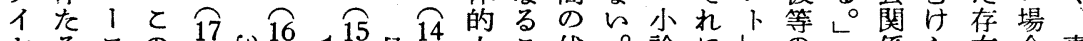
ヤるスの

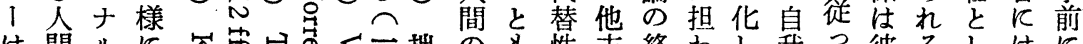

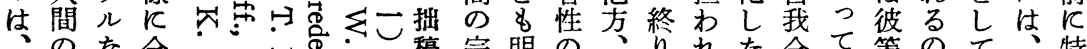

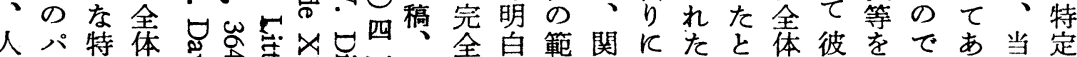

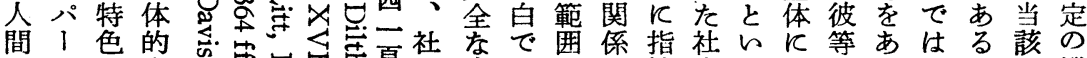
の

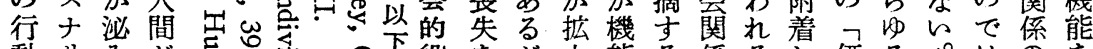

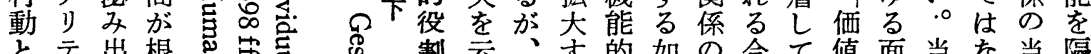

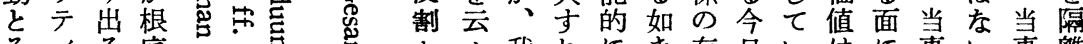
そ1る底 のの の К 諸把であ 種握ある のとるか 所的方 産 5 、 反問とそ? 対題と役 し反で割 て浲行の と着動具 り劣体 得る 通的 る。忘京 うつそ行 のての 解フ主は<smiles>[CH][CH-]</smiles>

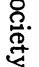

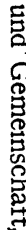

㺃

范

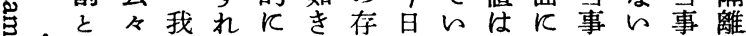

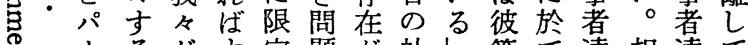
导 1 るがす定題が社し等て達相達て スと右るさを制会のの包は互はそ でナとに程れは度にで特みフの互の

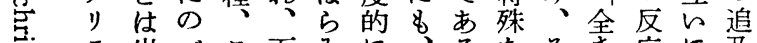

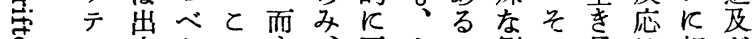
马イ来たの\&、要人 側の具は相だ の学通様普充求間面全体相手け 怘統々名な遍分さの。或存的手方が 一合の、事主注れか極は在な方に意 、でそ態義意てか端活に人のと龱 八人あのの的しいるに動まで限っさ $>$ 交る場寒志なるあっにであらてれ 豆研。合現向けとりゲで拡りれ範る き究ではにれと方ゼはが、た鯙の 四す困よばはがルなっ当側化で 巻ら難るなな、注るて該面さは 总全と全ると又十社机れな 
象て スてに手々定くが近外のすをし娶合現程比を釈

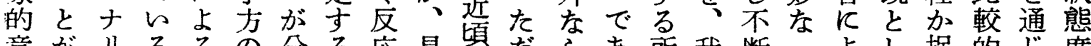
意がリるるの分る応具䝿だらあ哲我断 よし捉的じ度 味第テ脈行析制が体筩何なり謂々の心ってえ恒ての に二イ絡㞧動の度ど的ら時ら、、相理て、常\& 5

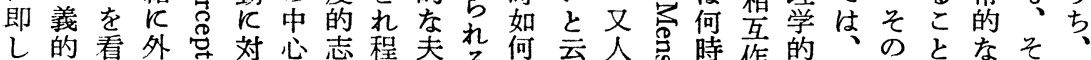

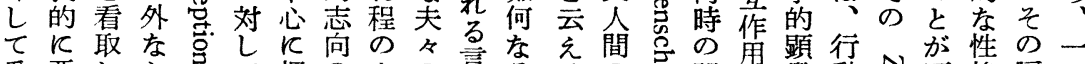

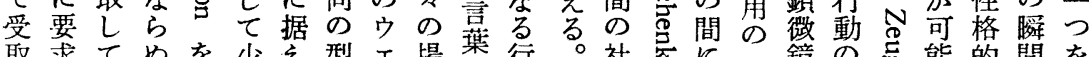
取求て如を少元型工場枼行。社突に渦鏡の品能的間を

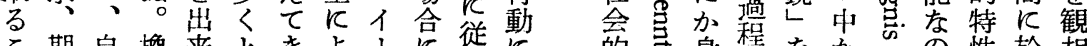

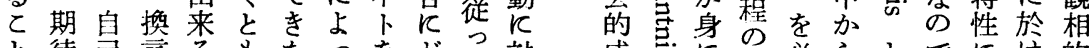

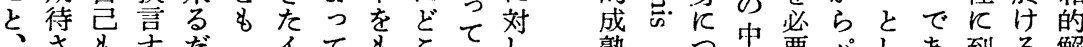

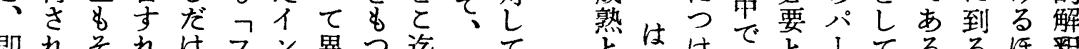

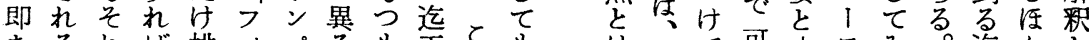

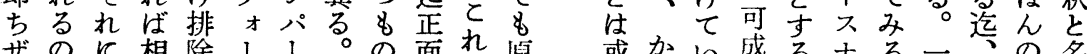
ザのに相除11。の面机原或から成るナる一各の ッで応手すマス従とを理るかる的とリと切行一付 八なじ方へルナつしつ它的意るす的とテとの動時汀

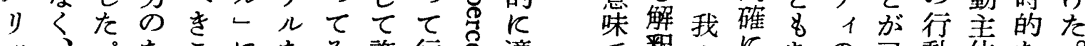

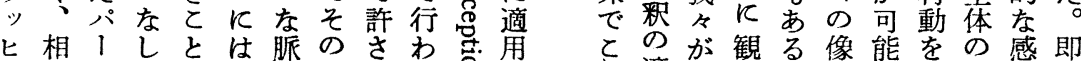

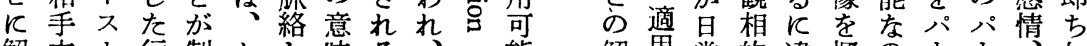

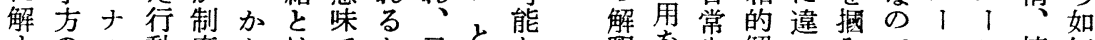
寸の儿動度かはでか又呼な釈を生解らみでスス情何 る行なか的る、ははと技通活粎な出あナナ緒に

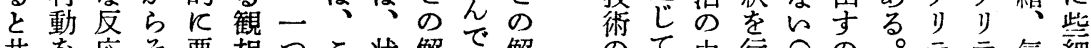
共老々要相つて桨解で解 少て中行 18 の。テテ気細

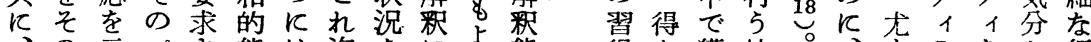
の示パさ態は迄を飞よ態得た獲技。、然のをか行 自対与 1 れ度相我規基岂度 $飞 \&$ 得術然微場表何ら動

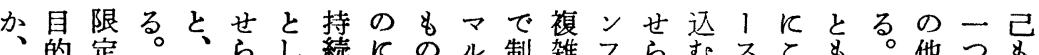
18 そ的定徉フれれて 続 れ達さつオる取、多せ呼領的組 1排がル種上しの核ザ

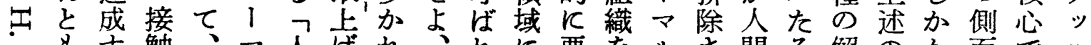
讨す触、マ人げれ、れに要をルさ間る解のか面で八 逆るやパル間ら少てて現求をしる.の釈通るにあり

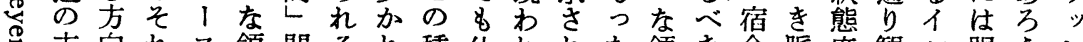
方向れス領関るれ種仕れれた領き命脈度観ン眼与七 日向にかナ域係に影の様てる企域とだ絡を相パを。

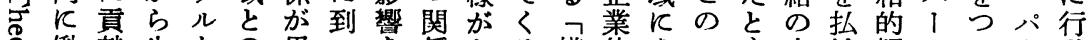

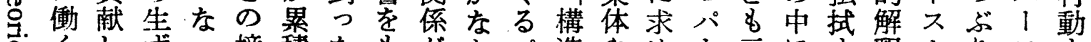

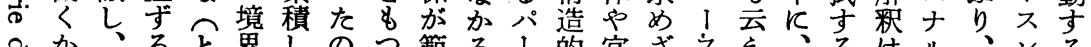
冬か、ると界しのつ範ろ

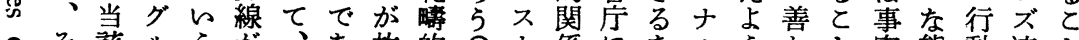

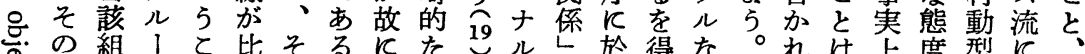

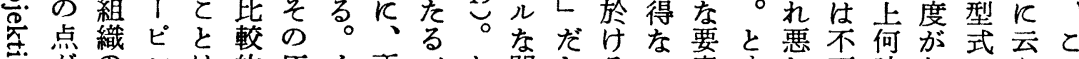

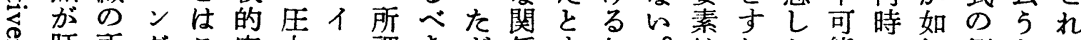
马肝所グと容力ン謂きだ係す如。はれか能で何側なが の要謂がの易がフフ構如はれくヒ・ばれに\&程面らイ

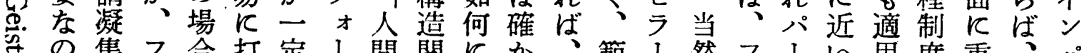

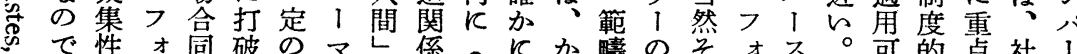

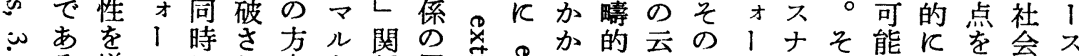

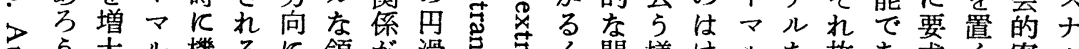

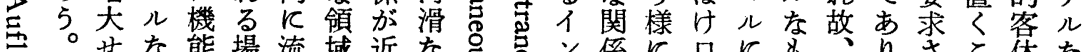

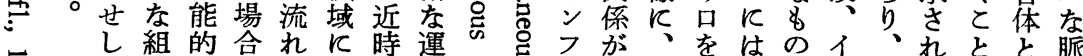

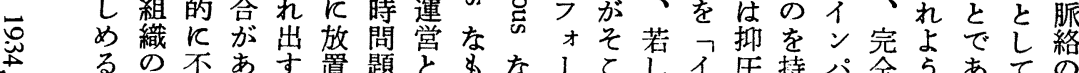


飞!触 とと当怒の或ネ役与期が体を側る

挙、をイ名が事、規る唯割と待許へ们面か以

げル可ン付要者恐定種テ期すでさ就いに\&上

たし及フけ求に怖はの待るあれ中て移知の

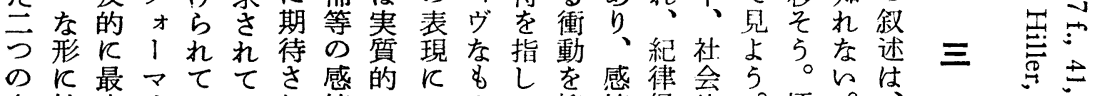

名於少りにいれ情飞ののて抑情保的。煩。

称て限テるるてや殆み\& 制的持客感を我と

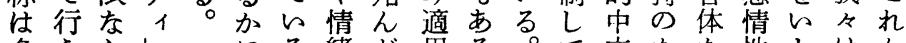

多5らし尤反る緒ど用る。て立たた性とはか

分としの多よかをとさし勿性わるのわ改ら

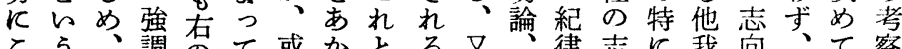

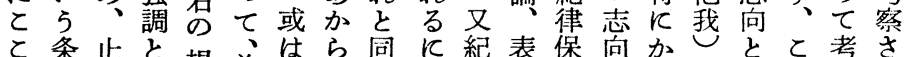

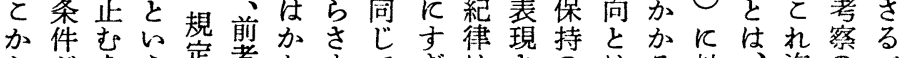

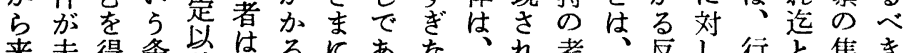

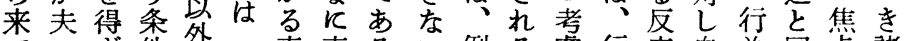
てィざ件多表表る々例る慮行応自為同点諸 ら附るが导現現。場え感息為老者様点 る加場前怘を即合情服者統にがに感を

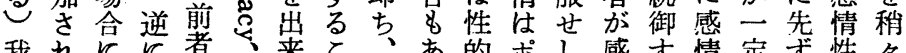
我れに者著と、あ的ポし感す情定ず性々 々ては後飞後ると愛るなジめ情る的桨公先 のは、者は者だが憎会感テな的必況、感取 考々そに直はけ、、严情々けな要応のス情し 察るれは接る抑社快。表ヴれ表のを中ン的た にがを直的导制会不し現なば現な示にズ中澸 と、フ接接怘す関快ヴの\&をを方すあの立み

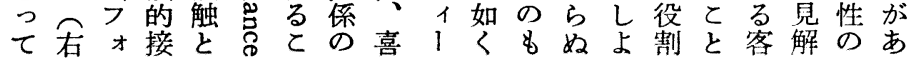

るる体 満的感 従足行情

つを為的

て抑者中

そえの立 と直变

只例壳

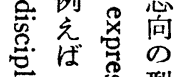

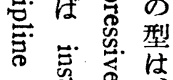

紀志な右

律哥関石

克导見

㞯な表た

配奛通

の虑す

要 $\sqrt{ }$ る 社

素従と会

が属と的

あせ 客

るしよ体

とめつK

と社

は 5 得す

云告らる

務も起医で占すクす等者待職れ 51 さ 222120

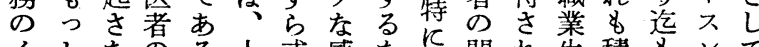

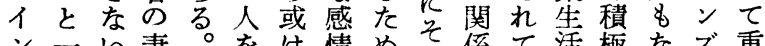
ン一に凄。を情めれ係て活極なズ重

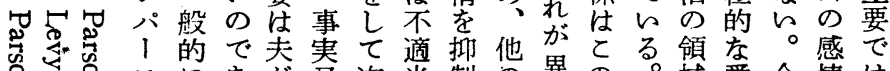

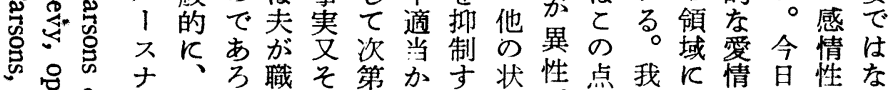

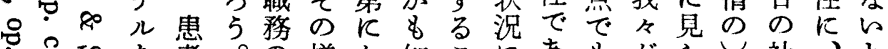

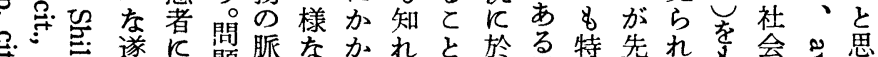

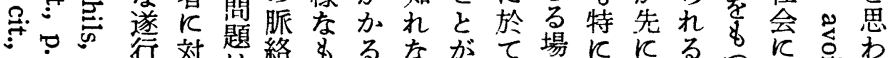

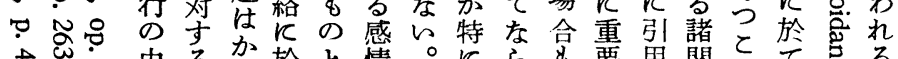

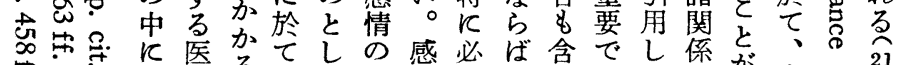
介著基て発情要或点あた壮が夫が制 ?入西性二生的と和る, 逆制婦感そ

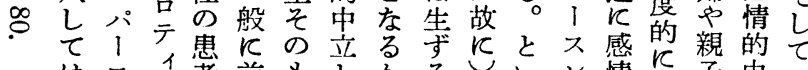

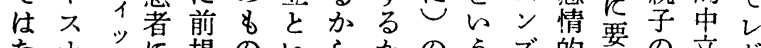
なナッ提のいらかかの らルク接され5。\&肉ののに沓関性 1 なな感しれ無制否知体は事中さ係に!

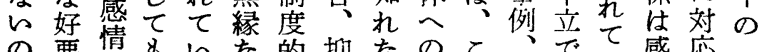
の悪情名々な的抑なのて

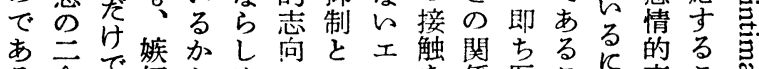

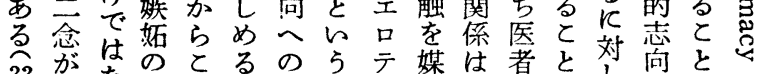

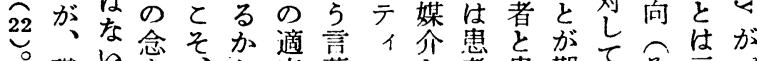


な純ラのなとの!もと通的るれでがとそは意意で迄

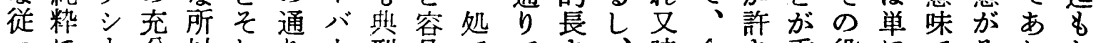
つKI分以れり！型易ででさ、時全さ重役にでそれな

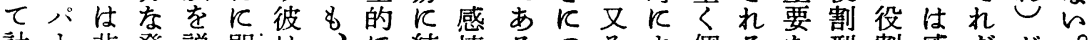
計 I 非発説即は、結情るつそょ個るな型割感だが。 算入人達くし、园現び的 出十間反とた先的わつ中 なな华必共行にこれく立 感れな、䉞がと志 感情ば条心. 予寸情、の向

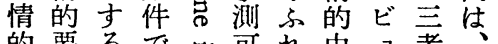
的要るで可れ中者者能 要素程あゆ能た立１省事 素が、る恕性通な口結実 が、換と 職般高を含王勘機シを能 務的れの、定の、は的 遂にばへのロ意のビ限 行云愛て原ク入義古工定 のっやい理ラれを舆 1及 過て憎るがシ得指的口び 程あ、。ビ、る摘分ク普 からそ即工に儿し析ラ遍 らゆのち、と、てをシ主 排る他ビ口つルい残，義 除非あこクてしるしのの さ合らはラ不の。た 中両 れ理ゆ口至可確周ウ飞志 れ的るク। 欠立知最向

23 $と っ 人$ 役の式型情け一た てでての割での式的制度だ す表は恣型あ内へと的規只 ら現積意式る容の感せ範

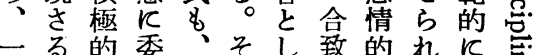
定べねそれてと中る型合 のき要らのば感ら立限式自 規感求れ表加情 5 の り化体

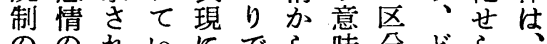
ののれいにでら味分どら 存種るる関はのでにん役役 吉類状訳しな中の係索微 るや況でて的立克わ役従令 と質関なら他要ががにてれ は反しい社人求問な役が レ\&て。会にさ題 $、$ 必割如 ヴ、もか的対れな。ず遂何 亿更社か規专ての従附行な 1反会る制る゙いでつ随者る が表的表を感るはてすの内 指現瞡現伴情と学々る。全容

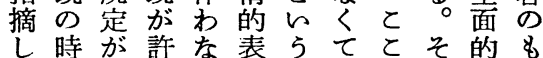
た間あさら現と、での恣の

易をな定自あにり割と間しに相とれるくバルが合とば

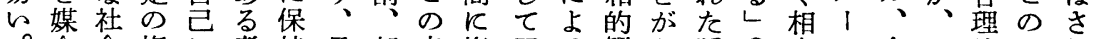
介会権 $飞$ 者持具部点権了る解必脈 $\widehat{25}$ 容

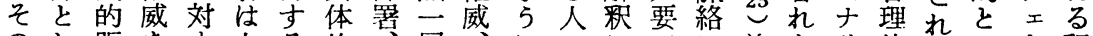

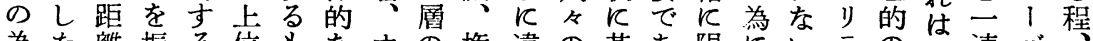

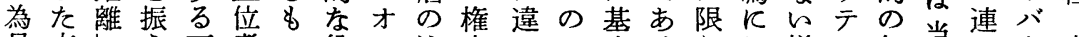

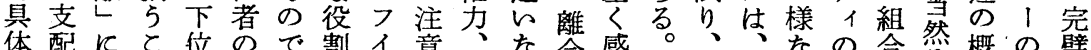

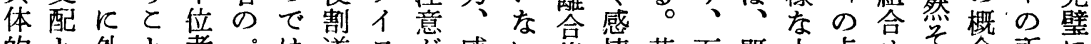

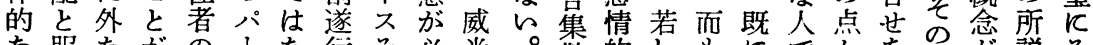
な服ながの!な行そ必光。散的し\&字でかを論が説そ 役従ら可パス者の要の殊は反全相考\& ら前論組のの

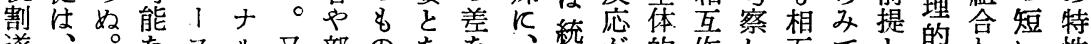

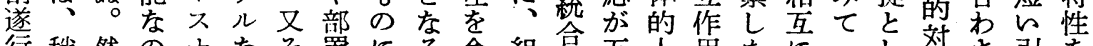

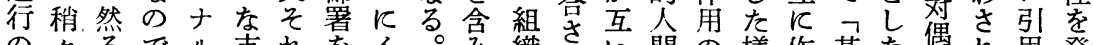
のタるで儿支れをイ。多織れ的間の様作甚な偶れ角発

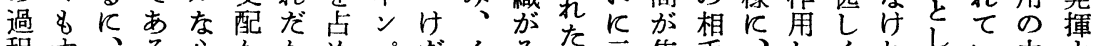

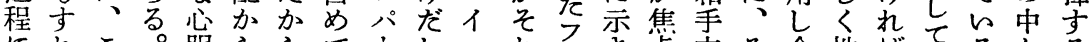
飞れと。服ららて、しエれる゙点方そ合性ばてるかる

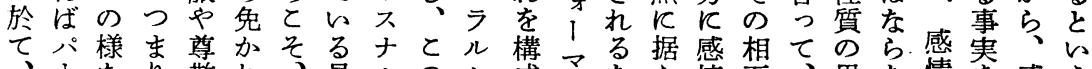
、1なり敬れ、具儿のシ成宁をえ情互、異な情を感 上: スイ七の得イ体に場 I 等ならら的作組つ的看情の 下ナンラ念るエ的具合的る組侍中角織たで中取的で 夫ルパ「のしラな備の要的織立を立をの立し

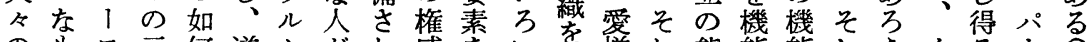
の\&ス云何逆シがれ威をらを兽れ態能能し 5 イる 1 亿4 地のナ 5 K六

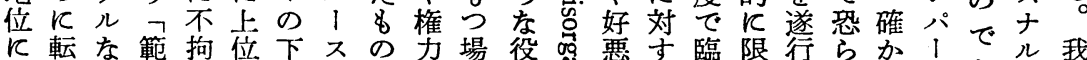

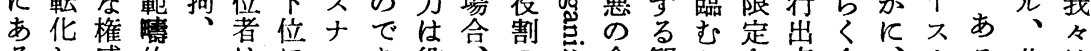

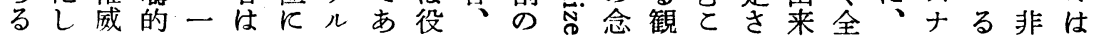


間置のは解とのるト対 5

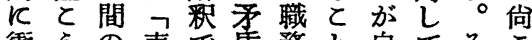

衝 5 の表で盾務と自でと

突守優現あすに的ろる喜よのゔのて

競る性しらでびう職ウつ感

合志を関。はやて務のは情

の向規心パな満種へ加先的

状な制之1 以足会云衣中

態の卞他スか感な5举立

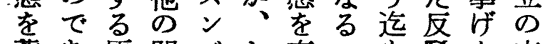

慧あ原関ズと有官䮎た志

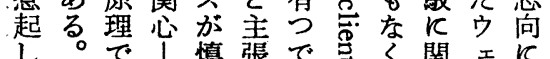

、前あで例重搷はか感し関、付

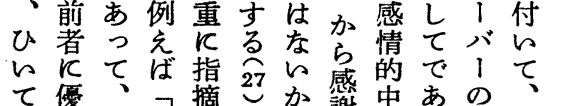

は位前角し性者ただ之さ立る。气 若

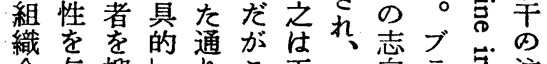

全与抑七多と正。向亏品注

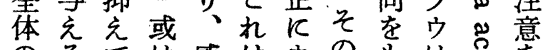

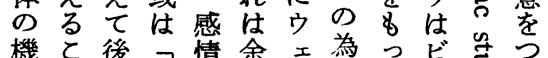

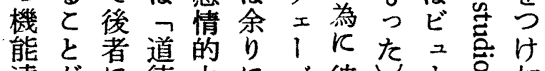

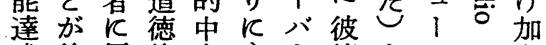

成後優的立81等を古の气

を者位しの浅のは遂ク原て

阻と性 1 志薄所自行亏理置

害のをと向な説导すッにと

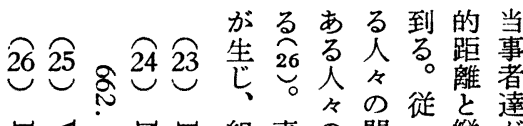

出尔卢組事の間つ縦が

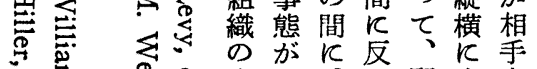

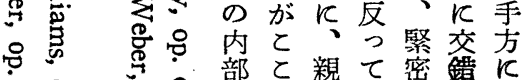

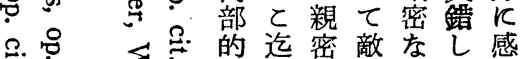

? 学芦的迄密敵なし感

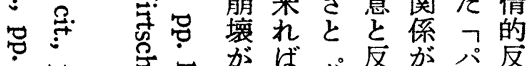

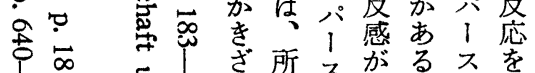

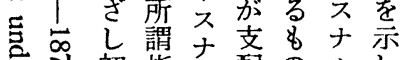

の初指儿配の儿し

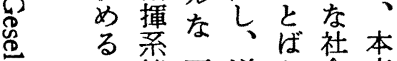

吉で統体逆加会来

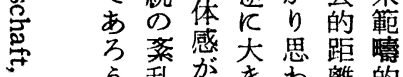

门。乱生をれ離的

命れ距てがあ

合るだい形っ

『達とた範さ等

ま の範躊れの

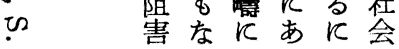

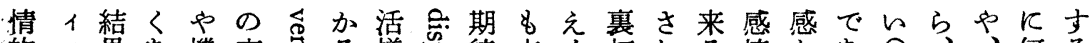

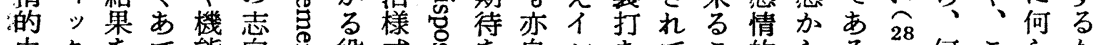
中クをて能向导役式总を自ン方てて的らる何とらか 立な招は的にさ割と念已合がいと中差。等の葛ら

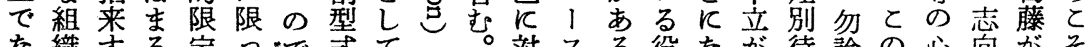

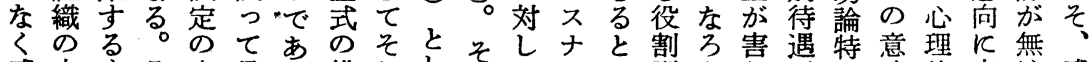

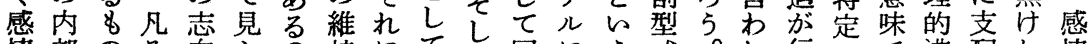

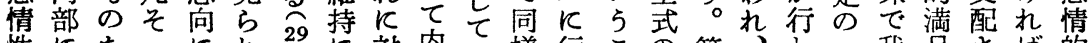

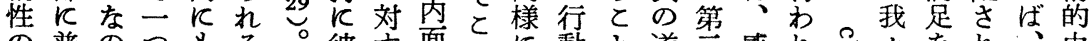

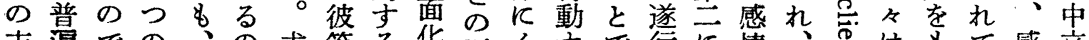

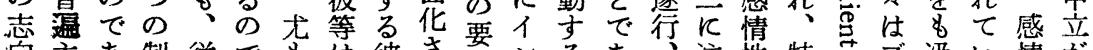
淌主あ制従でも彼さ求ンるあ注性特 ブ汲い情が が義る度つな、情等れ、と沓とる維意の別にラみる的要 はの。的てくと緒の期 1 と。持志の対ウと役表求 び代だ型そ、と的感待不主自そ心向考导のっ割現さ

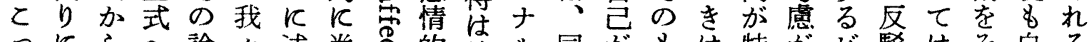

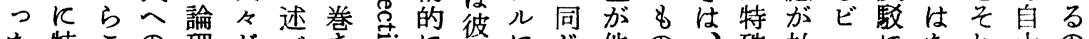

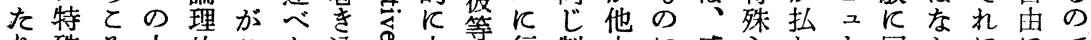
り殊之人的とた込心中行行制人反感主わ，同らににで 寸主間対れ事空立為動度には情義れ口意ぬ即許あ る義例の偶迄柄れ壳者す的対、的とたクすなしさる。

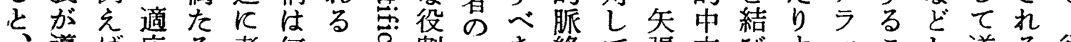
導ば応る考何つ导割欲き絡て張立びすッとと遂る徉

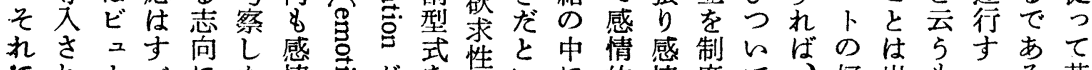

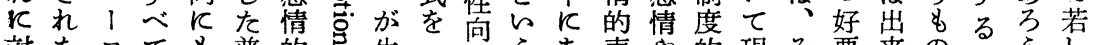

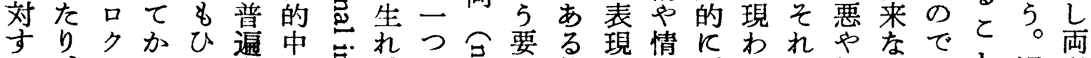

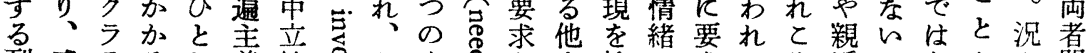

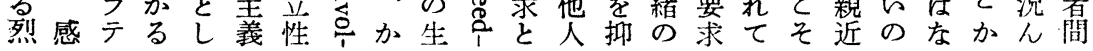




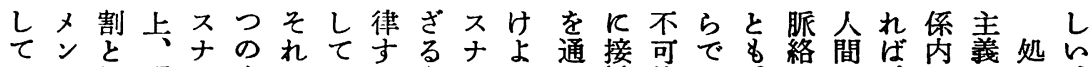
らト切現ル本はニるをル5で触能あ、のの、でので感

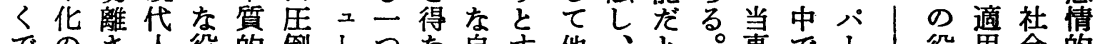
でのさ人役的倒1つな自吉他而と事で、|役用会的 あ原れは割な的口のら我る人而し我者はスそ割に関反

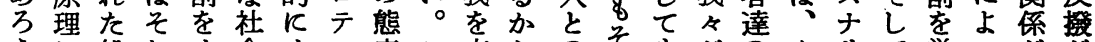

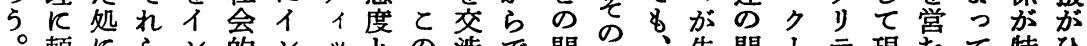
頼Kらン的ンッとの渉で間際先関、テ現むて特ひ

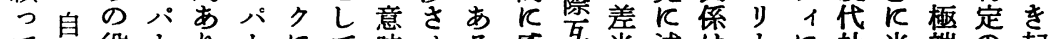

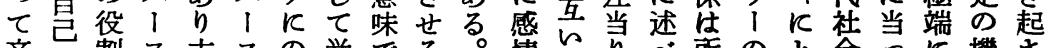
辛の割 $ス$ 方 5 をナをナみげはす表的棈彼た謂云っはて代能れ

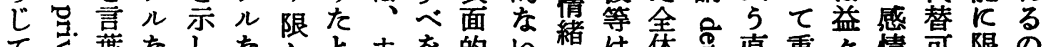

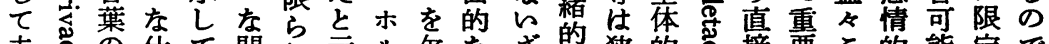

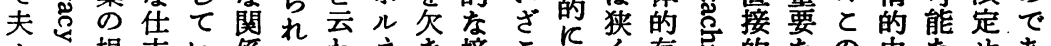
々根方係たわ的を接とはく存吉的なの中なせあ

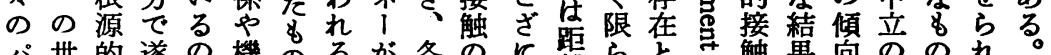

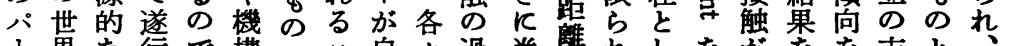

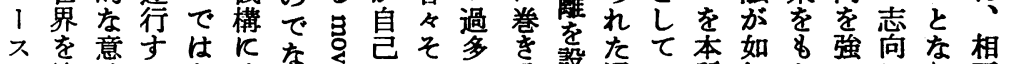

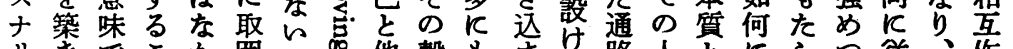

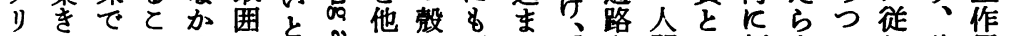

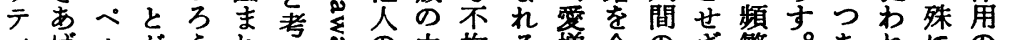

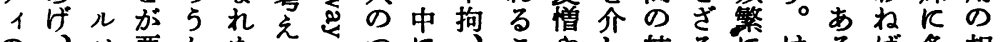

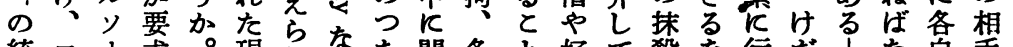

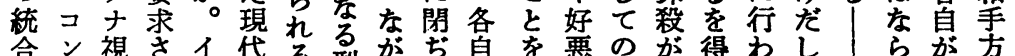
合ン視さイ代る型がち自を悪の㥂わし!らが方

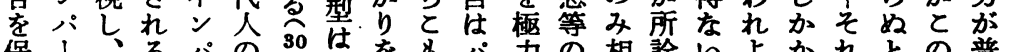

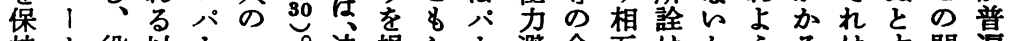

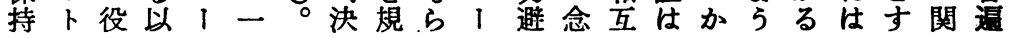

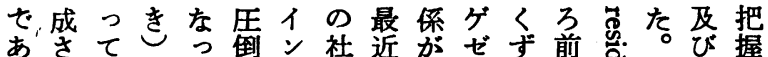

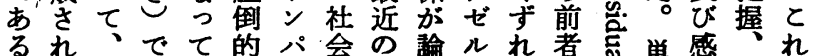

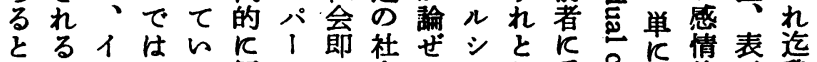
認処ン公る传不方会ら十し重导的示我

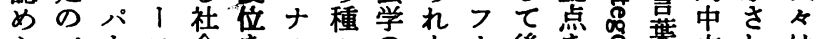

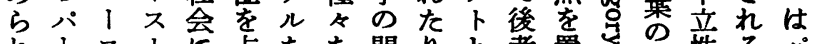
れ、スナ占なな問りと者置性るパ

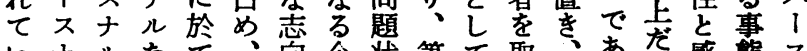
レナルなて、向企桨第て取、あ感蚝ス

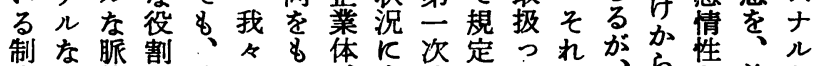

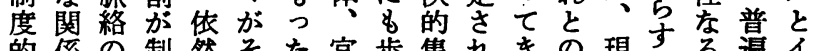
的係の制然そた官歩集れをの現杂逼入

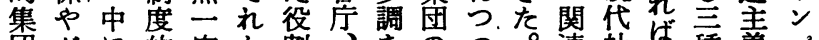
団グに的定か割、をのつ。連社㮔義パ とルイにのらを軍合再、と会、のと、 は1 ン之生虧組隊わ発而れ於公役特ス ピフの活れ織せ見もはて焦ン割殊ナ 共.ンォ存領て化政るがそ現、点染志ル

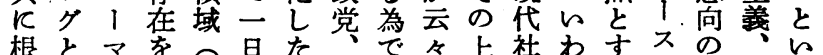
底本儿認例\&所労あせで会ばるナ型機 5

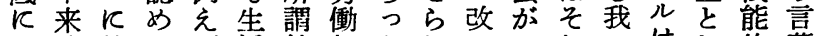
あ的然ら ば活第組たれめ一れ々はし的葉 るにしれ家を兰合。たて応かのパて限反 価公必て族営次、刎りフ類ら考 I考定上 值i然的生多的学論し人型の察不察とっ 志入的る活得集校城的逸はナし不て 向ナに。のな団等今にしに脱むルて限夫 の儿形従如くが、日る関は烄々

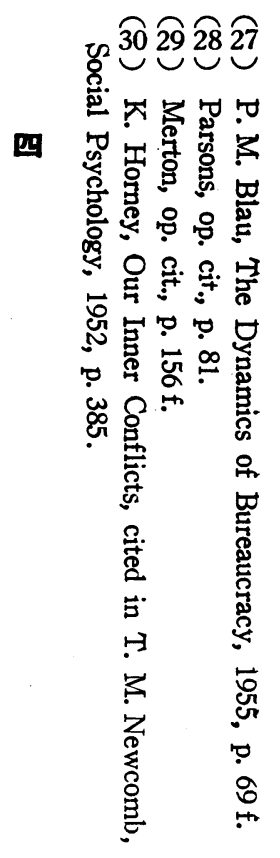




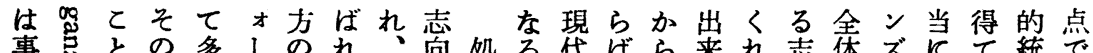

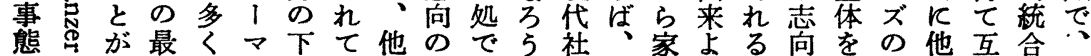

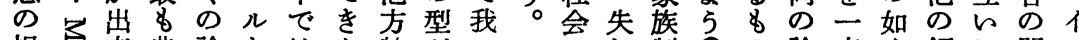

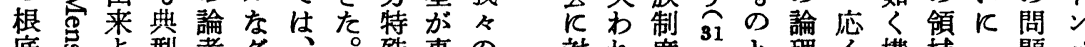
底员上型者 K与 5 的 8 儿家そ主害考 据品。を

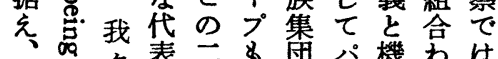

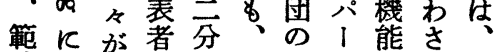

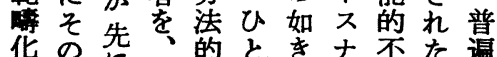

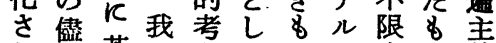
れ相若々方くのと定の義

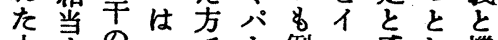
人守のマで 1 例ン感し機 間る学ッ事スえハ情て能 と処説 キ態ナ壮、性イ的 のの史、をル企スのン限 対+的ヴ分と業ナ組 パ定

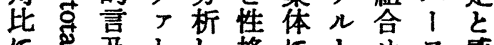

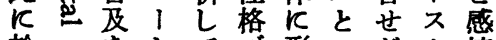
於ををとてゔ形いがナ情 て 分总たイるらさ対１の中 析際湆様れ極不名立 進交揭見ある。る的ナでの

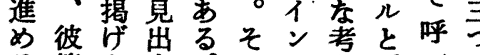
る等た守。しフ方呼ばの 対れ度理亿構域心題バ 寸よのしし的ン造に品を! る5 如尤方極 ハ息艿課

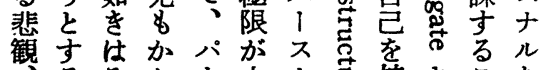

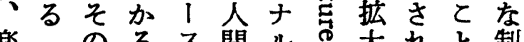
楽フのるス間ルる大れ制 観ゲ存機ナにな機しるは度 のマ在能ル課脈能よと云や 果イを的な寸絡分 5 と 5 集 しン排分眽るの析とは迄団 なシ護析絡或支のす中的的 らヤしををる配立る々な対 思フな目。種と場か困皇 弁卜け的命のしKら難。守 的しれ論焉緊て立でで夫る。

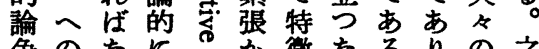

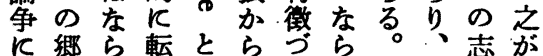
道愁ぬ䐆嫢のけ古と二向全

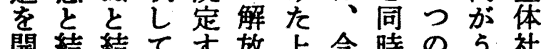

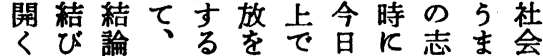

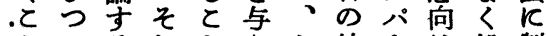
と的れと充か社1 は処制 にてなだ的てか会不不を度

成最的時礎そッな下右工的がス且と為求８人にィナの 程後考ににれキ関あの、などナうしにしせ間だしルで 我に文、迄は、係っ様シ第れリ何てははよにけとなあ 々問を右溯分光てな

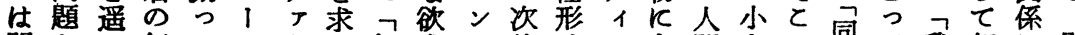
問と加叙てス”、 め組求の的式の8間さで同て我相火即 題しK述考ナ達る織充内集华命束のなは類如々対於ち 処て露は察儿の不の足と団さす緟参ク到仲何はして 家 理残骨すさと所城王の外過れるさ加儿底間な我、安族

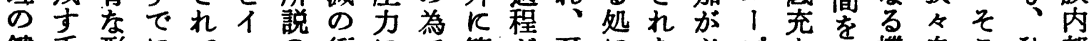
鍵手形にてンの衝にで筑が系にな必プた得機自とひ部 と掛でといパ引動抗あを統従い要のした能身でとで しり提れる、用をしりあイ化っ自で内得らをではしも てと示迄点スは生つ、げンさて苖あ部なと果あイく又

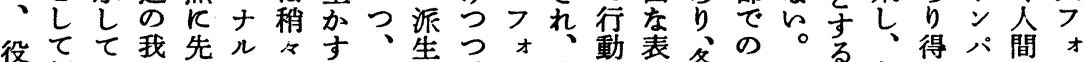

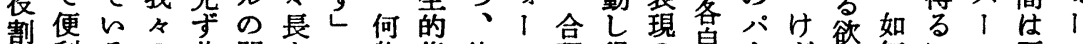
型利るの共問きと物集依、理得の貝、だ求何こ不互、

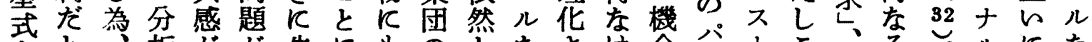

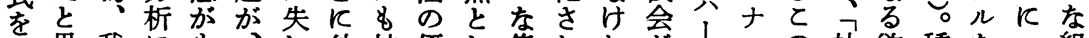

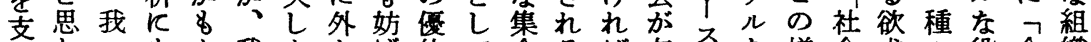

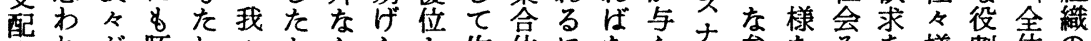
寸れが脴れ々かららと作体になえ充参なそを様割体の るた抱胎たとををれて用を到ら方架欲の充々型的中

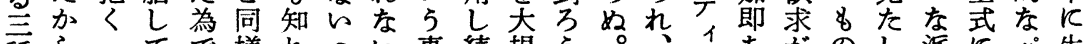
種ら二てで様れ

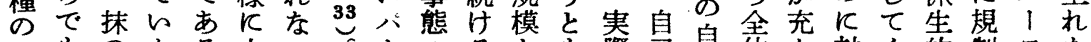

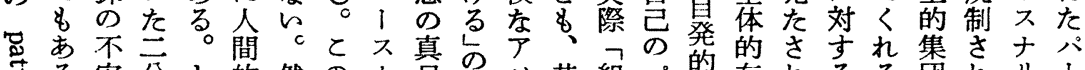

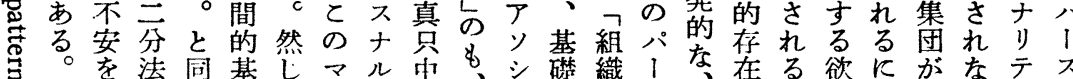


$\widehat{34} \widehat{33} \widehat{32}$

ない析がは川坚中論フ制がかる限ででズ二な

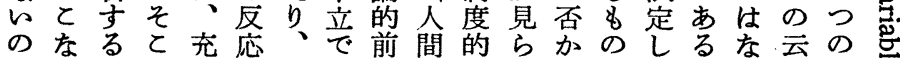

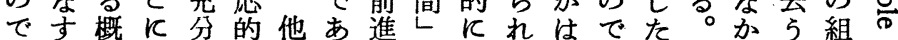
党写あだ念つ顧態方りは関認る慎はと然ろる合を

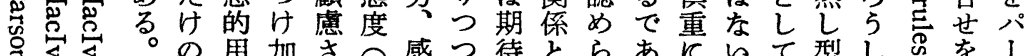

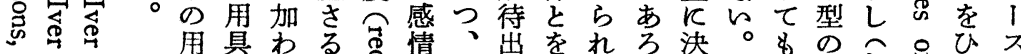

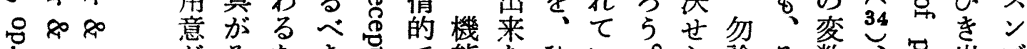

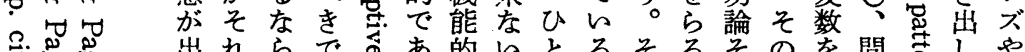

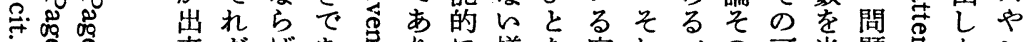

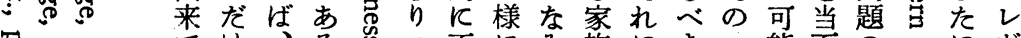

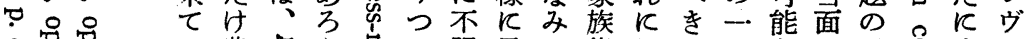

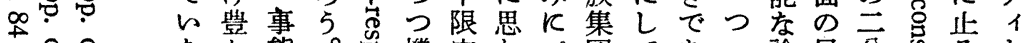

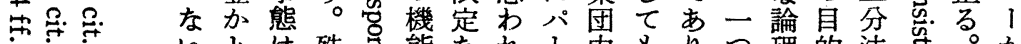

귬요

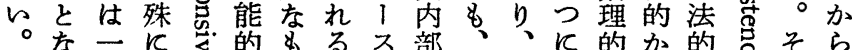

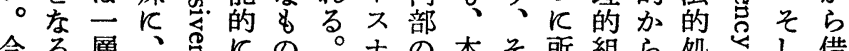

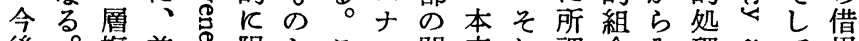
後。複普雭限ととル関来れ謂合み理等て角

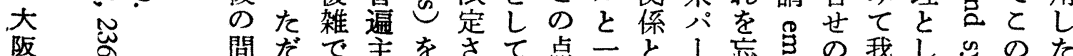

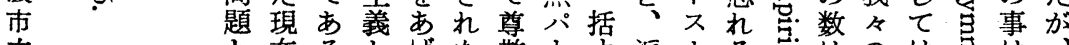

立

学

助

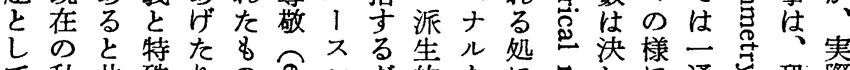

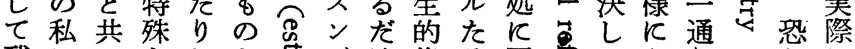
残に主しと市ズけ集る园灾てたりからに

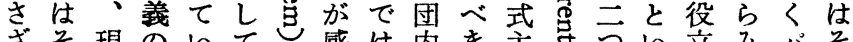

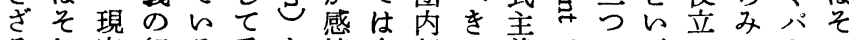
るれ奏組る受を情余部と義がに三竞て、と ををを合と容あ的りでとのあ止種た不スか 得使分せと的げに理のを幣るをにの当ンら

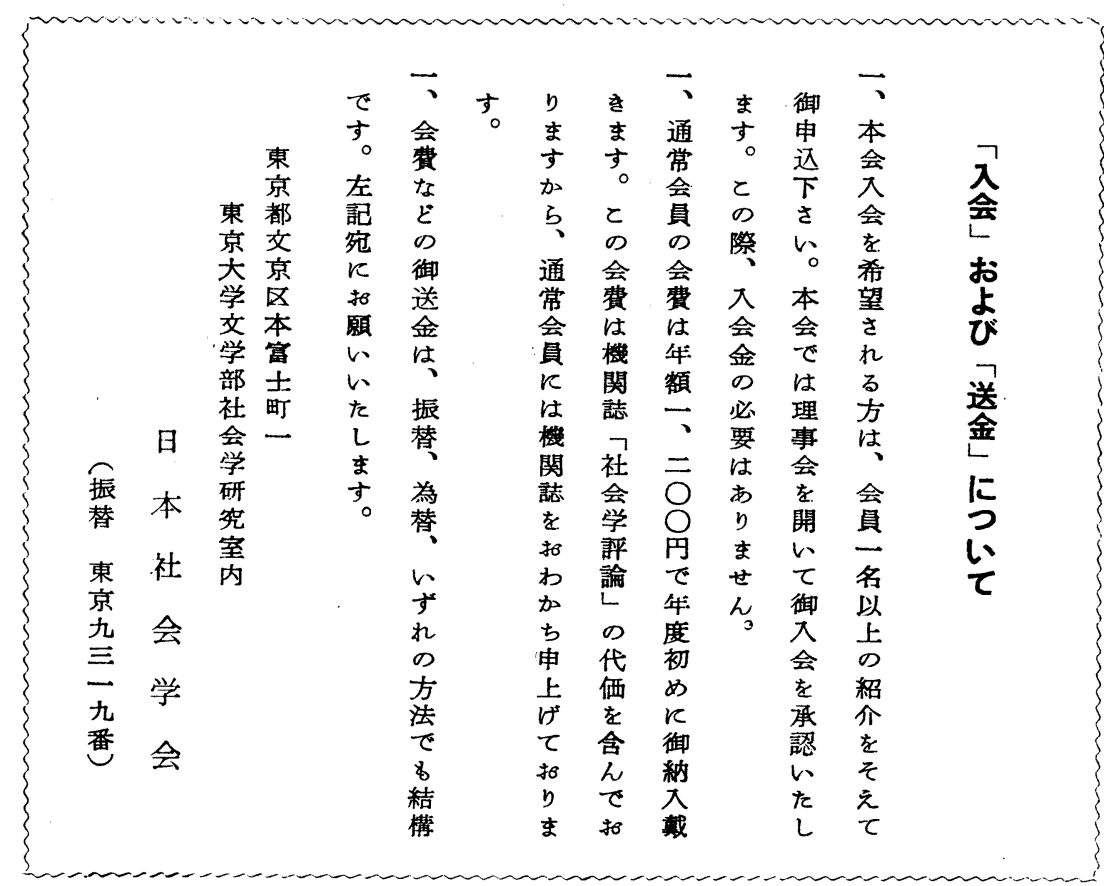




\section{Personal and Impersonal}

\section{Yoshio :Mori}

\section{Osaka City University}

We find the paired terms-personal : impersonal-often used in the recent sociological literature. Like many other terms these have diverse meanings according to the context, in which they are used. So we should try to define them accaratary and systematically. For this purpose we fined the clue in parsons' "pattern variables of role expectation," especially those of Universalism, : particularism, specificity; diffuseness and affective neutrality; affectivity, From them we derive two combinations, i.e. particularism-diffuseness-affectivity and universalism-specificity-affective neutrality and the formes as "personal" in contrast to the latter as "impersonal." This problem can not adequately be analyzed, we believe, without a definite conception of man as "total human being." In this sense the paper deals with the relation of organization and man in its modern phase.

\section{Toward an Understanding of Parsons Theory of Dinensions and Phase Movement}

Tatsuo Matsuno Gifu University

Parsons deals with the central subject matters of sociology on the structuralfunctional level on one side, and on the level of dimension and phase movement on the other. If sociological thought should be evolved with the action frame of reference of man as its core, and if Parsons is primarily interested in the making of the general theory of action, he should stand only on the level of dimension and phase movement. For the structural-functional level necesserily leads to the theories of middle range, and the making of the general theory would be possible only by standing the level of dimention and phase movement.

Now I'd like to prove my argument. The whole system of his theory is connected with the three concrete levels of the five pattern variables-personality level (personality system), group level (social system), and cultural level (cultural system). Those are understood to show the dimensional structure concerning the individual organism which contains the actor. They are analyzed in terms of the frame of reference of action space, and the frame of reference of action -motivated effort, chein of ends and means, situation and normas that of space-G, E, A, and I dimensions-and that of time-G. I. A. and $L$ pheses-are all to be understood in dimensional structure. And not only action, individual organism, space and time themselves can be understood in dimentional structure in a wider sense, but there exists a unified situation among them. Moreover, since action and time unfold themselves, what constitute dimensional structure at each of those stages are made dynamic, and are on the level of phase movement.

In the above treatment, of course, only the general and formal aspect of Parson's theory has been taken up, leaving the psychological aspect untouched, although it is equally important. A systematic analysis taking into account both of those aspects is, therefore, yet to be done. 